\title{
Shape engineering boosts antibacterial activity of chitosan coated mesoporous silica nanoparticle doped with silver: a mechanistic investigation
}

D. Sen Karaman, S. Sarwar, D. Desai, Emma Björk, Magnus Odén, P. Chakrabarti, J. M. Rosenholm and S. Chakraborti

\section{Linköping University Post Print}

\section{Tweet}

N.B.: When citing this work, cite the original article.

Original Publication:

D. Sen Karaman, S. Sarwar, D. Desai, Emma Björk, Magnus Odén, P. Chakrabarti, J. M. Rosenholm and S. Chakraborti, Shape engineering boosts antibacterial activity of chitosan coated mesoporous silica nanoparticle doped with silver: a mechanistic investigation, 2016, Journal of materials chemistry. B, (4), 19, 3292-3304.

http://dx.doi.org/10.1039/c5tb02526e

Copyright: Royal Society of Chemistry

http://www.rsc.org/

Postprint available at: Linköping University Electronic Press

http://urn.kb.se/resolve?urn=urn:nbn:se:liu:diva-129179 


\title{
Journal Name
}

\section{ARTICLE}

\section{Shape engineering boost antibacterial activity of chitosan coated mesoporous silica nanoparticle doped with silver: A mechanistic investigation}

Received 00th January 20xx, Accepted 00th January 20xx

DOI: $10.1039 / x 0 x \times 00000 x$

www.rsc.org/

\author{
D. Șen Karaman, ${ }^{a, d \#+}$ S.Sarwar, ${ }^{\text {b\# }}$ D. Desai, a E. M.Björk, ${ }^{c}$ M. Odén, ${ }^{c}$ P. Chakrabarti, ${ }^{b}$ J. M. \\ Rosenholm, ${ }^{\text {a }}$ and S. Chakraborti ${ }^{\text {be\#t }}$
}

\begin{abstract}
In this study mesoporous silica nanoparticles (MSPs) of different size and shape were developed, and their surface coatings altered to study their differential effect in enhancing the antibacterial activity. In brief, MSPs with three different aspect ratios 1, 2 and 4 were prepared, doped with silver ions and finally coated with the polymer chitosan. Both Gram-positive and Gram-negative bacteria were treated with the MSPs. Results indicated that silver ion doped and chitosan coated MSPs with the aspect ratio 4 (Cht/MSP4:Ag+) has the highest antimicrobial activity among the prepared series. Further studies revealed that Cht/MSP4:Ag ${ }^{+}$was most effective against Escherichia coli (E.coli) and least effective against Vibrio cholerae ( $V$.cholerae). To investigate the detailed inhibition mechanism of the MSPs, the interaction of the nanoparticles with E.coli membranes and its intracellular DNA was assessed using various spectroscopic and imaging-based techniques. Furthermore to increase the efficiency of the MSP combinatorial antibacterial strategy was also explored - nanoparticles in combination with kanamycin (antibiotic) was treated against Vibrio Cholerae (V. cholerae). Toxicity screening of these MSPs was conducted against Caco-2 cells, and the results show that the dose used for antibacterial screening is below the limit of toxicity threshold. Our findings show that both shape and surface engineering contributes positively towards bacteria killing, and the newly developed silver ion-doped and chitosan-coated MSP has good potential as an antimicrobial nanomaterial.
\end{abstract}

\section{Introduction}

Infectious diseases still constitute considerable risks for disabilities and death, especially in the developing countries. In the global burden of disease study, infectious diseases were estimated as being responsible for $22 \%$ of all deaths and $27 \%$ of disability-adjusted life worldwide. ${ }^{1}$ One of the most common reasons for infectious diseases is bacterial invasions. The most common bacterial infections range from minor skin infections to acute diarrheal disease. The bacterium can be transmitted from infected animals or their products, and they can enter the human body through the intestines (ingestion), lungs (inhalation), or skin (cutaneous). The most common source of infections requiring hospitalization is Staphylococcus aureus (S.aureus), accounting for $18.8 \%$, followed by E.coli, accounting

a Pharmaceutical Sciences Laboratory, Faculty of Science and Engineering, Åbo Akademi University, Tykistökatu 6A, Turku, Fl-20520, Finland.

b Department of Biochemistry, Bose Institute, Kolkata 700054, India.

c Nanostructured Materials Division, Department of Physics, Chemistry and Biology, Linköping University, SE-581 83, Sweden

$d$ Laboratory of Physical Chemistry, Faculty of Science and Engineering, Åbo Akademi University, Porthansgatan 3-5, Turku, Fl-20500, Finland

e Department of Chemistry, Indiana University, Bloomington, Indiana, USA.

+Corresponding Authors: Soumyananda Chakraborti (soumyabiochem@gmail.com) D. Șen Karaman (dsen@abo.fi)

\# Equal contribution

Electronic Supplementary Information (ESI) available: [details of any supplementary information available should be included here]. See DOI: 10.1039/x0xx00000x for $17.3 \%$. Among outpatient infections, E. coli is the most common organism (38.6\%). ${ }^{2} \mathrm{~V}$. cholerae is the dominant bacterial cause of severe secretory diarrhea, and still a significant cause of mortality and morbidity. ${ }^{3} \mathrm{~V}$. cholerae is a Gram-negative, comma-shaped bacterium, and there are more than 200 known $V$. cholerae serogroups reported, although only $\mathrm{O} 1$ and $\mathrm{O} 139$ strains are directly connected to pathogenesis and cause epidemics. ${ }^{4}$ According to recent WHO reports, the annual acute diarrheal cases for $V$. cholerae infection in southeastern and central Asia were estimated as more than 1 million. Particularly the children populations are found to be highly susceptible for this infection. ${ }^{5}$

For many years, antibiotics have been used to inhibit or kill these pathogenic bacteria. However, antibacterial resistance has also developed over time, which is becoming a growing problem. Attempts have been made to overcome the bacterial resistance to antibacterial drugs by discovering new antibiotics and chemically modifying existing antimicrobial drugs. Unfortunately, there is no guarantee that the new drug developments can out-compete pathogen's fast and frequent developed resistance in a timely manner. This seriously threatens human health, especially when the drug-resistant infections in hospitals and in communities are considered.6,7 There is thus need for exploring novel platforms for overcoming antibacterial resistance. One of the most promising strategies is to utilize antibacterial nanomaterial's to combat resistance, as well as to develop nanocarriers for effective delivery of antibiotics to bacteria. ${ }^{8}$ 
In the past decades, different research groups have reported that metal and metal oxide nanoparticles (such as silver, zinc, copper, titanium, magnesium, and gold nanoparticles), polymeric nanoparticles, carbon nanotubes, nano-emulsions and nitrogen oxide-releasing nanoparticles are effective against pathogenic microorganisms; while liposomes, solid lipidpolymer-, and dendrimer-based nanomaterials have been employed as carriers for antibiotics. 9,10 The preparation of such antibacterial nanomaterials could be cost-effective as compared to antibiotics synthesis, and they are also robust for long-term storage with a prolonged shelf-life. In addition, some nanoparticles can endure conditions under which conventional antibiotics are inactivated. Among the framework of developing new antibacterial nanostructured materials, mesoporous silica particles (MSPs) can be one of the forerunners. Silica nanoparticles (NPs) are becoming popular due to their high thermal and chemical stability, and good biocompatibility. ${ }^{11,12}$ Among different forms of silica NPs, MSPs are increasingly being utilized due to their versatile nature; they can, amongst others, be prepared in a wide variety of shapes and sizes. Literature shows that the uses of mesoporous silica materials have grown explosively in the last decade in the biomedical field ${ }^{13,14}$ and studies have confirmed its success as diagnostic and therapeutic nanomedicine. ${ }^{15}$ Another important trait that can easily and flexibly be tuned in the case of MSP is surface chemistry, which can, for example, provide better cellular internalization tandem with controlled release of incorporated agents. In addition, their characteristic high surface area $\left(\geq 1000 \mathrm{~m}^{2} / \mathrm{g}\right)$, pore volume and adaptable surface functionalization ${ }^{16}$ can also be beneficial to employ MSPs themselves as efficient antibacterial agents for combating antibacterial resistance, and to potentially induce synergetic effects with the existing antibiotics and/or be utilized as vehicles to carry antibiotics and deliver to bacteria. Furthermore, a controlled release of antibiotics can be provided by polymer coating of the MSP surfaces. ${ }^{17}$ Additionally, extensive usage, leakage and accumulation of antibacterial metal nanoparticles can be prevented in the environment by employing MSPs with multiple functions/properties, which are ultimately biodegraded to harmless products in the presence of water. ${ }^{18}$ This is highly important in protecting the environment and beneficial bacteria from the metal nanoparticles for the sake of the ecosystem. ${ }^{19}$ Recently, the antibacterial activity of silver-silica nanocomposites was demonstrated 20 however, detailed understanding of the designed material and the exact mechanism of action is still elusive. Very little insight into the antibacterial properties of silica nanoparticles exists in the literature. Therefore, we aimed to consider two of the most decisive physicochemical properties of mesoporous silica nanoparticles: the effect of shape (morphology) together with a surface coating on the antibacterial activity.

In the present study, mesoporous silica nanoparticles (MSPs) were prepared with different aspects ratios and designed with silver ion doping and a chitosan surface coating, as shown in Scheme 1. As a special focus, we have investigated the effect of MSPs with different aspect ratios and surface coating to enhance the antibacterial activity and further studied if an additive or synergistic effect could be achieved in the presence of the antibiotic kanamycin. We chose this specific antibiotic, as several studies have reported that resistance frequently occurs against this antibiotic. ${ }^{21,22}$ To study the inhibitory effect on bacteria, MSPs with different aspect ratios (ARs) 1, 2 and 4 were prepared, doped with silver ions and further coated with the chitosan polymer. The synthesized MSPs were characterized and finally treated against both Grampositive and Gram-negative bacteria. We found that both aspect ratio and surface coating influence the antimicrobial properties of MSPs. Our experiments further revealed that chitosan coated and silver ion doped mesoporous silica nanoparticles (Cht/MSP: $\mathrm{Ag}^{+}$) with the aspect ratio of 4 had the highest antibacterial potential. To understand the inhibition mechanism of the above-mentioned NPs, the interaction between the nanoparticles and E.coli membranes were assessed (E.coli was chosen, as it was found most susceptible bacterium on NP treatment). To improve the efficacy of MSPs against $V$. cholerae, the synergistic antibacterial effect of MSPs in combination with kanamycin was also studied. Finally, we conducted toxicity screening of these MSPs against a number of cell lines, and we found that the dose we used for antibacterial screening is below the toxicity threshold of NP. Shape engineering of MSPs with different aspect ratios and synergism observed with kanamycin would be useful from the perspective of the development of antibacterial nanomedicines.

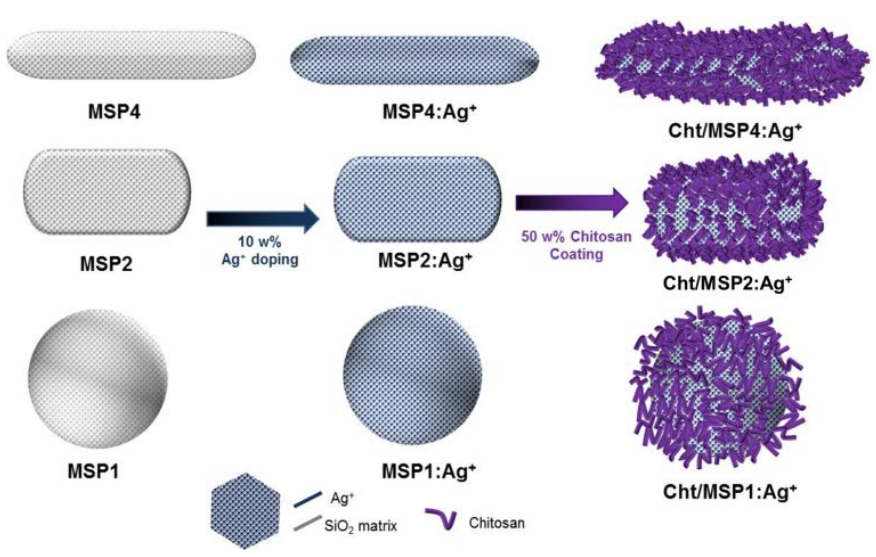

Scheme1. Schematic presentation of prepared MSPs for antibacterial activity tests

\section{Methods and Materials}

\section{Reagents and Organisms}

For the synthesis of MSP with different aspect ratios, tetraethyl orthosilicate (TEOS) (reagent grade, 98\%, Aldrich), aminopropyl tetraethoxysilane (APTES) were used as silica sources. Hydrochloric acid (purity $\geq 37 \%$. p.a., Fluka, ACS Reagent, fuming), triblock copolymer EO20PO70EO20 (P123) (reagent grade, 99\%, Aldrich), heptane (99\%, Reagent Plus, SigmaAldrich), ammonium fluoride (purity $\geq 98.0 \%$, p.a., ACS reagent, Fluka), absolute ethanol (purity $\geq 99.7 \%$, ALTIA), cetyltrimethylammonium bromide (Sigma), sodium hydroxide (Merck) were used as received for the synthesis. Milli-Q water 
$(18.2 \Omega)$ was used throughout the study. Luria Broth (HiMedia), folin's reagent (SRL), PBS buffer saline, glutaraldehyde, ethanol (Merck), kanamycin (HiMedia), DAPI (Sigma) were procured. $V$. cholerae classical strain (0395) was obtained from the laboratory of Dr. Ranjan Kumar Nandy of National Institute of Cholera and Enteric Diseases (NICED), Kolkata, India and maintained in our laboratory. E. coli (MTCC 433) and S. aureus (MTCC 3160) strains used here were obtained from MTCC, India.

\section{Synthesis of mesoporous silica nanoparticles}

MSPs with different aspect ratios (MSP1, MSP2 and MSP4) were prepared with the following protocols. MSP1 was prepared by employing MCM-41 type material synthesis protocol, carried out in basic solution and cationic surfactant (CTAB) was employed as structure directing agent. Briefly, $0.23 \mathrm{~g}$ of $\mathrm{NaOH}$ pellets were dissolved in $20 \% \mathrm{v} / \mathrm{v}$ ethanol solution $(400 \mathrm{~mL})$. After that $0.83 \mathrm{~g}$ of CTAB was added to the solution and stirred at room temperature until dissolved. Finally, $44 \mu \mathrm{L}$ of APTES was added, followed immediately by the addition of $4.2 \mathrm{~mL}$ solution of TEOS. The solution was kept stirring at room temperature overnight. After that, the product was centrifuged, washed with ethanol once, dried and calcined at $550^{\circ} \mathrm{C}$ for $6 \mathrm{~h} . \mathrm{MSP} 2$ and MSP4 samples were prepared according to SBA-15 type mesoporous material synthesis protocols and the earlier developed synthesis protocol was employed to obtain certain aspect ratios. ${ }^{23,24}$ In their synthesis, $2.4 \mathrm{~g}$ of $\mathrm{P} 123$ (triblock copolymer) and $28 \mathrm{mg}$ of $\mathrm{NH} 4 \mathrm{~F}$ were added to $80 \mathrm{~mL}$ of $1.84 \mathrm{M}$ $\mathrm{HCl}$. The acidic mixture was stirred at $20^{\circ} \mathrm{C}$, until the polymer was dissolved. $1 \mathrm{~mL}$ (MSP2) or $17 \mathrm{~mL}$ (MSP4) in heptane was premixed with $5.5 \mathrm{~mL}$ of TEOS and added to the micellar solutions. The solutions were stirred for $4 \mathrm{~min}$ and then kept under static conditions at $20^{\circ} \mathrm{C}$ for $1 \mathrm{~h}$. The solutions were transferred to PTFE flasks for hydrothermal treatment at $100^{\circ} \mathrm{C}$ for $24 \mathrm{~h}$. The products were filtered, washed with distilled water, dried, and finally calcined at $550^{\circ} \mathrm{C}$ for $5 \mathrm{~h}$.

\section{Silver ion $\left(\mathrm{Ag}^{+}\right)$doping and surface modification of MSPs}

The steps involved in the preparation of multifunctional MSPs, starting from pristine MSPs, are presented in Scheme 1. First, $\mathrm{Ag}^{+}$doping was carried by dispersing MSPs in acetate buffer $(10 \mathrm{mM}, \mathrm{pH}: 5.5)$ and adding $10 \mathrm{w} \% \mathrm{AgNO}_{3}$ relative to the mass of MSPs to the suspension. The doping of $\mathrm{Ag}^{+}$was carried out at the concentrations of $3 \mathrm{mg} / \mathrm{mL}$ nanoparticles suspension for $3 \mathrm{~h}$ which was well above the solubility limit of silica in water $(120 \mathrm{ppm}) .{ }^{25}$ After that, the samples were collected by centrifugation, washed once with distilled water and dried under vacuum. Furthermore, the surface modification of MSPs was achieved by the electrostatic adsorption of chitosan in acetate buffer (at pH: 5, 10mM) after drying of $\mathrm{Ag}^{+}$doped MSPs and re-dispersing them in chitosan solution. The surface modification by chitosan was employed in order to enhance the dispersibility of MSPs and prevent the leakage of silver ion from the MSPs in suspension.

\section{Characterization of MSP}

Sizes of pristine MSPs were investigated in dry form by statistical analysis of transmission electron microscopy images obtained by FEI Tecnai 12 TEM (FEI Co., Hillsboro, OR, USA) operated at $12 \mathrm{kV}$. The statistical analysis was carried out by analyzing, at least, 150 MSPs particle via ImageJ software. ${ }^{26}$ The aspect ratios and overall morphology of MSPs were investigated by scanning electron microscopy (SEM) (Leo 1550 Gemini scanning electron microscope) operated at $3 \mathrm{kV}$. In order to explore fine structure of pristine MSPs and $\mathrm{MSPs}_{\mathrm{Ag}} \mathrm{Ag}^{+}$and possible crystalline formations after $\mathrm{Ag}^{+}$doping of MSPs pristine samples (MSP1,MSP2, MSP4) and $\mathrm{Ag}^{+}$doped MSPs (MSP1:Ag+,MSP2:Ag+, MSP4:Ag') were imaged by G2 TF 20 UT and Tecnai 12 TEM (FEI Co, Hillsboro, OR, USA) operated at 200 $\mathrm{kV}$ and $120 \mathrm{kV}$ respectively. Powder X-ray diffraction method (PXRD) with a Kratky compact small-angle system (MBraun, Nottinghamshire, UK) was employed in order to investigate the mesoscopic ordering of MSPs before and after $\mathrm{Ag}^{+}$doping of MSPs. The structural parameters related to the mesoporosity (surface area, pore size and pore volume) were determined by nitrogen sorption measurements utilizing Autosorb 1 (Quantachrome, Boynton Beach, FL, USA) for MSP1 and ASAP 2020 (Micromeritics Instrument Corp., Norcross, GA, USA) for MSP2, MSP4. The surface area values were obtained by the application of Brunauer-Emmett-Teller (BET) theory and the pore size distribution of MSP1 was obtained by density functional theory (DFT) and Kruk-Jaroniec-Sayari (KJS) method was used for MSP2 and MSP4 samples.

The change in the net surface charge of MSPs was determined in acetate buffer $(10 \mathrm{mM}$ at $\mathrm{pH} 5)$ by $\zeta$-potential measurements (Malvern ZetaSizer, NanoZS). A further confirmation of surface modification with chitosan coating on MSPs was carried out by thermogravimetric analysis (TGA, Netzsch STA 449F1 Jupiter) after proper drying and accurate weighing of the samples. The TG resolution of this instrument is $0.025 \mu \mathrm{g}$ and the measurements were done under air atmosphere and in alumina crucibles, at the scanning rate of $10 \mathrm{~K} / \mathrm{min}$. During the measurements, thermograms were recorded within the range of $30-850 \square \mathrm{C}$ and the results were analyzed with the help of software Proteus 5. The calculation of chitosan extent on MSPs was carried out in the temperature range of $225-650^{\circ} \mathrm{C}$ which was determined as chitosan degradation temperature range prior to analysis. Atomic absorption spectroscopy (AAS) method was employed to determine the extent of $\mathrm{Ag}^{+}$on MSPs after $\mathrm{Ag}^{+}$doping.

\section{The release of silver ions from MSPs:Ag and Cht/MSPs: $\mathrm{Ag}^{+}$}

The release of silver ions from MSPs (1/2/4), MSPs (1/2/4): $\mathrm{Ag}^{+}$ and Cht/ MSPs (1/2/4): $\mathrm{Ag}^{+}$) were investigated in HEPES buffer $\left(25 \mathrm{mM}\right.$ at $\left.\mathrm{pH} 7.2,36^{\circ} \mathrm{C}\right)$ during $24 \mathrm{~h}$. Accurately weighed MSPs were dispersed in HEPES buffer with a concentration of $500 \mu \mathrm{g} / \mathrm{mL}$. For this part of the study, Spectra/Por ${ }^{\circledR}$ Float-ALyzer ${ }^{\circledR} \mathrm{G} 1$, Ready-to-Use laboratory dialysis devices were used. The released silver ion concentrations was measured by ICP-AES (PerkinElmer, Optima 5300 DV) analysis. Samples of each time point were measured 3times, and the average value of the 
measurements was used to plot the $\mathrm{Ag}^{+}$release profiles from MSPs.

\section{Antibacterial tests}

A single colony was picked and inoculated into $5 \mathrm{~mL}$ Luria Broth (LB) medium. The LB was then incubated at $37^{\circ} \mathrm{C}$ for overnight with shaking at 200rpm. From this overnight grown pre-culture $10^{6} \mathrm{CFU} / \mathrm{ml}$ of test bacteria strain was inoculated into $20 \mathrm{~mL} \mathrm{LB}$ broth contained in the $100 \mathrm{~mL}$ conical flask. The cultures were then supplemented with all the prepared samples of MSPs (MSPs (1/2/4), MSPs (1/2/4): $\mathrm{Ag}^{+}$and Cht/ MSPs (1/2/4): $\mathrm{Ag}^{+}$ resulting in a final concentration of $50 \mu \mathrm{g} / \mathrm{mL}$. Then the cultures were incubated at $37^{\circ} \mathrm{C}$ with constant shaking at 200rpm. The same procedure was followed for all the test bacterial strains. Growth kinetics of untreated and MSP-treated bacterial cells was determined by measuring the change in $O D$ at $600 \mathrm{~nm}$ after every $1 \mathrm{~h}$.

The percentage of growth inhibited after the treatment with MSP was calculated by using the formula given below:

$$
\% \text { Inhibition }=\frac{(\text { OD of untreated }- \text { OD of MSP-treated })}{\text { OD of untreated }} \times 100
$$

\section{MIC}

By definition MIC endpoint represents the concentration of Cht/MSP4:Ag+ at which there is no visible growth of bacteria. The minimal inhibitory concentration of $E$. coli cells was determined by a broth micro-dilution method. For this purpose 100ul of 5 different concentration of Cht/MSP4: $\mathrm{Ag}^{+}$containing $10^{5} \mathrm{CFU} / \mathrm{ml}$ bacterial culture was placed into 96-well flatbottom microtiter plates and incubated at $37^{\circ} \mathrm{C}$ for overnight. The optical density of the culture was measured using Tecan Microplate reader at a wavelength of $595 \mathrm{~nm}$.

\section{Effect of chitosan coated and silver ion doped MSPs on the morphology of bacterial cells}

From the overnight grown culture of E.coli $10^{6} \mathrm{CFU} / \mathrm{ml}$ of bacterial strain was inoculated into $5 \mathrm{~mL} L B$ and then supplemented with MSP1:Ag+, MSP2: $\mathrm{Ag}^{+}, \mathrm{MSP} 4: \mathrm{Ag}^{+}$and Cht/MSP1: $\mathrm{Ag}^{+}, \mathrm{Cht} / \mathrm{MSP} 2: \mathrm{Ag}^{+}, \mathrm{Cht} / \mathrm{MSP} 4: \mathrm{Ag}^{+}$samples resulting in the final concentration of $50 \mu \mathrm{g} / \mathrm{mL}$. Control experiments were conducted without MSP. The cultures were then incubated at $37^{\circ} \mathrm{C}$ for $4 \mathrm{~h}$ with continuous shaking at $200 \mathrm{rpm}$. After the incubation period, cultures were centrifuged at 6000 rpm. The supernatant was discarded and the pellet was washed thrice with PBS (phosphate buffer saline) and was finally diluted 100times with PBS buffer. Diluted samples were then put as a drop on $1 \mathrm{~cm} \times 1 \mathrm{~cm}$ glass plate and air-dried. The samples were then fixed with $2.5 \%$ glutaraldehyde for $30 \mathrm{~min}$. The samples were further washed with water three times and then gradually dehydrated with $25 \%, 50 \%, 75 \%, 90 \%$ and $100 \%$ ethanol at room temperature. The samples were then visualized by Scanning Electron Microscope (FEI Quanta-200 MK2) with an accelerating voltage of $20 \mathrm{kV}$. Multiple fields of visions were viewed at different magnifications and best images were captured.

\section{Effect of MSPs on the amount of protein leakage}

The difference in the amount of protein leaked due to most effective MSP (Cht/MSP4: $\mathrm{Ag}^{+}$) treatment was estimated by Folins-Lowry method. For this assay overnight grown culture of bacterial cells was centrifuged, washed 3 times and finally suspended in PBS. MSPs were added to the bacterial suspension to attain a final concentration of $50 \mu \mathrm{g} / \mathrm{ml}$. Control experiments were performed without MSPs. The samples were then incubated at $37^{\circ} \mathrm{C}$ for $4 \mathrm{~h}$ with continuous shaking at 200rpm. After incubation, the samples were centrifuged and the supernatants were collected and the concentration of protein leaked was finally measured by Folins-Lowry method.

\section{Membrane fluidity assay}

Membrane fluidity was determined using 1,6-diphenyl-1,3,5hexatriene (DPH) as a fluorescent probe. Overnight grown bacterial cultures were inoculated into the fresh LB medium and grown to $\mathrm{OD}_{600}$ of 0.6. Bacteria were centrifuged, washed with PBS and finally resuspended in PBS and diluted one tenth of its initial concentration. Then the suspension was supplemented with $50 \mu \mathrm{g} / \mathrm{mL}$ of $\mathrm{Cht} / \mathrm{MSP} 4: \mathrm{Ag}^{+}$and incubated for $90 \mathrm{~min}$ at $37^{\circ} \mathrm{C}$. MSPs exposed cells were further recovered by centrifugation followed by washing and finally suspended in PBS containing $5 \mu \mathrm{M} \mathrm{DPH}$ and incubated for $1 \mathrm{~h}$ in dark at $37^{\circ} \mathrm{C}$. After incubation cells were washed to remove excess DPH and finally suspended in PBS. Control experiments were performed without MSPs. SDS (sodium dodecyl sulfate), which is known to damage the membrane, was used as positive control for the treatment of $E$. coli. The fluorescence of the cells was measured using Hitachi F-7000 fluorescence spectrophotometer. The fluorescence anisotropy of the probe was measured by exciting it with vertically polarized light $(\lambda \mathrm{ex}=360 \mathrm{~nm})$, and emission intensity was detected in both parallel and perpendicular planes $(\lambda$ em $=431 \mathrm{~nm})$. Final Results were obtained by subtracting unlabeled control sample. The polarization index was determined using the following formula:

$$
\mathrm{pI}=\left[\mathrm{I}_{\mathrm{V}}-\mathrm{I}_{\mathrm{H}}\left(\mathrm{I}_{\mathrm{HV}} / \mathrm{I}_{\mathrm{HH}}\right)\right] /\left[\mathrm{I}_{\mathrm{V}}+\mathrm{I}_{\mathrm{H}}\left(\mathrm{I}_{\mathrm{HV}} / \mathrm{I}_{\mathrm{HH}}\right)\right]
$$

Where, $\mathrm{I}$ is the fluorescence intensity and the subscript $\mathrm{V}$ and $\mathrm{H}$ corresponding to vertical and horizontal orientation values of the instrument.

\section{Flow Cytometer based DNA content analysis}

DNA accumulation inside the cell due to the treatment of $\mathrm{Cht} / \mathrm{MSP} 4: \mathrm{Ag}^{+}$was monitored using 4',6-diamidino-2phenylindole (DAPI). DAPI has specific affinity for A-T rich nucleic acid stretch of DNA. The fluorescence intensity of DAPI was directly proportional to the amount of DNA in the cell. ${ }^{27}$ Here overnight grown culture of $E$. coli was first collected by centrifugation, washed and then resuspended in PBS buffer. $10^{6}$ $\mathrm{CFU} / \mathrm{mL}$ cells were treated with MSPs at the concentration of $50 \mu \mathrm{g} / \mathrm{ml}$ for $4 \mathrm{~h}$. At the end of the exposure, cells were washed twice with PBS to remove excess nanoparticles and then incubated with $0.3 \mu \mathrm{g} / \mathrm{ml} \mathrm{DAPI}$ at $37^{\circ} \mathrm{C}$ for $1 \mathrm{~h}$. Control 
experiments were performed without MSPs. After staining with DAPI, excess stain was removed by washing. Finally, the fluorescence of cell suspension was measured using FACSVerse (BD Biosciences) equipped with BD FACSSuite software. The data were averaged over three identical experiments.

\section{Additive effect of Cht/MSPs (1/2/4): $\mathrm{Ag}^{+}$and kanamycin on $\mathrm{V}$. cholera}

$10^{6} \mathrm{CFU} / \mathrm{ml}$ of $V$ cholerae cells were grown in $5 \mathrm{~mL}$ LB medium supplemented (in three separate tubes) with $5 \mu \mathrm{g} / \mathrm{ml}$ of kanamycin, $50 \mu \mathrm{g} / \mathrm{ml}$ of Cht/MSPs: $\mathrm{Ag}^{+}$and $5 \mu \mathrm{g} / \mathrm{ml}$ kanamycin +

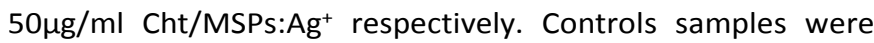
made without incubating MSPs and antibiotic. These cultures were subjected to incubation at $37^{\circ} \mathrm{C}$ for $6 \mathrm{~h}$ with continuous shaking at 200rpm. The OD was then measured at every hour at $600 \mathrm{~nm}$.

\section{In vitro cytocompatibility of Cht/MSPs (1/2/4): $\mathrm{Ag}^{+}$}

Caco-2 (human colon adenocarcinoma) cells were used for cytocompatibility assay of Cht/MSPs (1/2/4): $\mathrm{Ag}^{+}$. These cells are widely used as an in vitro model for small intestinal epithelial cell mimic, they can also undergo spontaneous differentiation (in culture) that leads to the formation of a monolayer of cells, express several morphological and functional characteristics of the mature enterocyte. ${ }^{28}$ Therefore we have used enterocyte-like Caco- 2 cells as a small intestine epithelial model, to evaluate possible toxicity of MSPs. Caco-2 cells were obtained from ATCC (Manassas, VA,USA) and maintained in DMEM medium (Sigma, St. Louis, MO, USA) supplemented with $10 \%$ fetal calf serum (BioClear, Wiltshire, UK), $2 \mathrm{mM}$ L-glutamine, $100 \mathrm{U} / \mathrm{ml}$ penicillin, $100 \mu \mathrm{g} / \mathrm{ml}$ streptomycin at $37^{\circ} \mathrm{C}$ in a $5 \% \mathrm{CO}_{2} / 95 \% \mathrm{O}_{2}$ and $90 \% \mathrm{RH}$ atmosphere and handled under sterile conditions. Caco- 2 cells were plated at a density of 5000 cells per well into the 96 -well plates and incubated overnight. After that, the cell medium was removed and replaced with $100 \mu$ medium containing different concentrations of Cht/MSP 1: $\mathrm{Ag}^{+}$, Cht/MSP 2: $\mathrm{Ag}^{+}$, Cht/MSP $4: \mathrm{Ag}^{+}(25,50$ and $100 \mu \mathrm{g} / \mathrm{ml})$ for $24 \mathrm{~h}$. Four replicates were used at each concentration and only cell media was added to the negative control (NC) group. Phenylarsine oxide is tyrosine phosphatase inhibitor and is used as a positive control for the study. Phenyl arsine oxi1de $(10 \mu \mathrm{M})$ was added to the positive control (PC) group. After incubation, $10 \mu \mathrm{l}$ of WST-1 reagent was added to the plate and incubated for 90min (standard incubation time) at $37{ }^{\circ} \mathrm{C}$ in the presence of $5 \% \mathrm{CO}_{2}$. The absorbance of the colored formazan was measured at $430 \mathrm{~nm}$ wavelength using TECAN ULTRA Microplate Reader (Tecan Group Ltd., Männedorf, Switzerland). The relative cell viability percentage in each group was calculated by comparison to the negative control group.

\section{Results}

\section{Characterization of MSPs and release of $\mathrm{Ag}^{+}$from MSPs}

MSPs with three different aspect ratios (AR:1,2,4) were successfully prepared, doped with silver ions $\left(\mathrm{Ag}^{+}\right)$and subsequently surface-coated with chitosan polymer by physical adsorption. ${ }^{29}$ The size distributions of MSPs were obtained by performing detail statistical analysis of TEM images for MSP1, MSP2 and MSP4 samples as presented in Fig. 1.
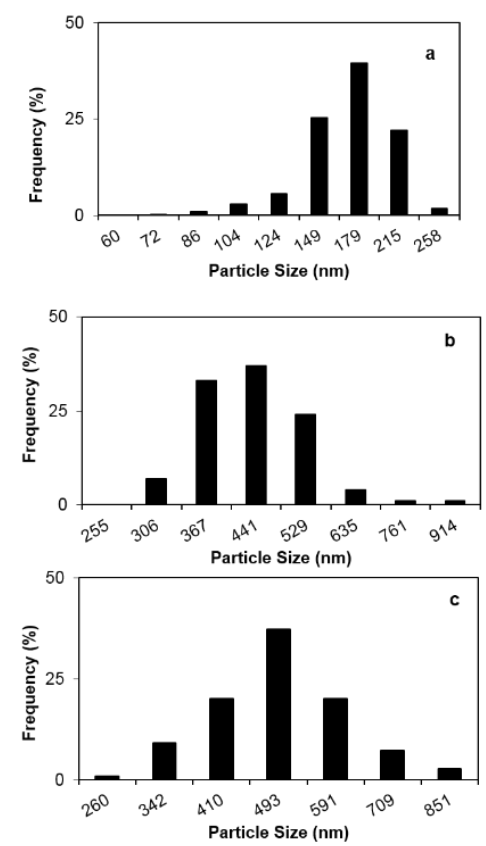

Fig. 1 Particle Size distribution of a) MSP1 b) MSP2 and c) MSP4 samples based on TEM images. The TEM images of the overall pristine MSPs are presented in Fig. S1 of supporting information.

The surface area and pore size distribution of pristine MSPs were determined by nitrogen sorption measurements. The pore size distribution of the samples are presented in Fig. S2 (supporting information) along with (Table S1) which presents surface area and the average pore size values of pristine MSPs. The calculated surface area values of MSP1, MSP2, and MSP4 are $915,583,575 \mathrm{~m}^{2} / \mathrm{g}$ respectively. The average pore size values are $3.8 \mathrm{~nm}$ for MSP1, $11.4 \mathrm{~nm}$ for MSP2, and $14.2 \mathrm{~nm}$ for MSP4. The $\mathrm{N}_{2}$ physisorption isotherms from the MSPs are also presented in Fig S2. All the presented isotherms are type IV, where MSP1 have a type 4 hysteresis loop, typical for MCM41 type material with accessible mesopores while type 1 hysteresis loops were obtained for MSP2 and MSP4 samples, typical for the ordered, cylindrical pores in SBA-15. The unit cell parameter of the MSPs was measured from the recorded diffractograms of powder X-ray diffraction analysis and the values are 4.3, 12.9, $15.3 \mathrm{~nm}$ for MSP1, MSP2 and MSP4 respectively.

Morphology investigation and structural integrity assessment of pristine MSPs and Ag+ doped, chitosan coated samples (Cht/MSP1:Ag ${ }^{+}, \mathrm{Cht} / \mathrm{MSP} 2: \mathrm{Ag}^{+}, \mathrm{Cht} / \mathrm{MSP} 4: \mathrm{Ag}^{+}$) were performed by SEM imaging. As presented in Fig. S3, the morphology of the prepared samples are preserved after the modification processes. Furthermore, MSP1: $\mathrm{Ag}^{+}, \mathrm{MSP} 2: \mathrm{Ag}^{+}$, MSP4:Ag+ samples were subjected to TEM analysis with two objectives, to check the fine structure of MSPs and also examine the presence of any trace of crystallization silver salts on MSPs. No significant distortions in the morphology of MSPs: $\mathrm{Ag}^{+}$were 
observed (Fig. 2) after $\mathrm{Ag}^{+}$doping process and the fine structures of particles are also retained (Fig. S4). In addition, no crystal formation was observed on MSPs after $\mathrm{Ag}^{+}$doping.

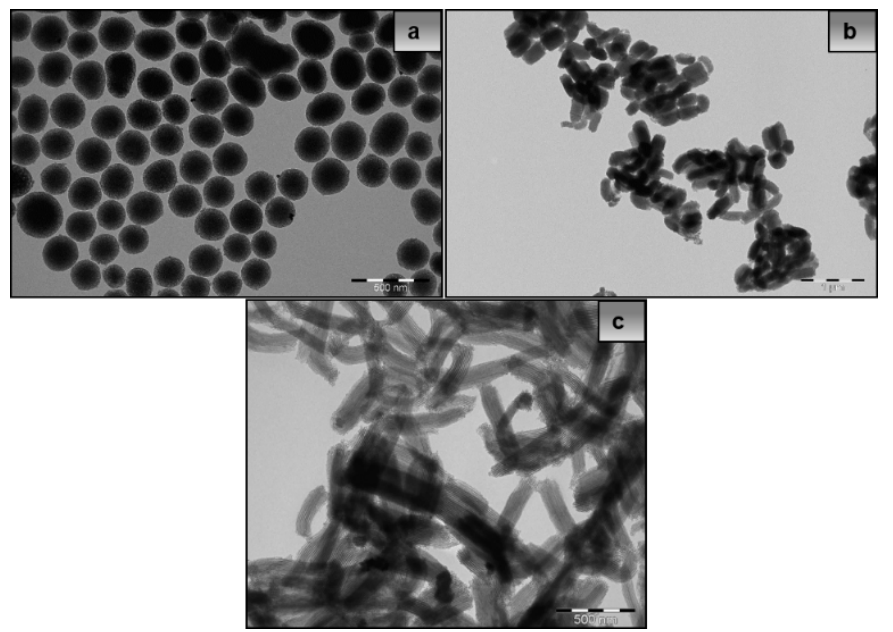

Fig. 2 TEM images of a) MSP1:Ag+(scale bar $500 \mathrm{~nm}$ ), b) MSP2: $\mathrm{Ag}^{+}$(scale bar $\left.1 \mu \mathrm{m}\right)$, and c)MSP4: $\mathrm{Ag}^{+}$(scale bar $500 \mathrm{~nm}$ )

The powder X-ray analysis diffractograms (Fig. 3) further showed that the mesoscopic orderings of MSPs are retained (hexagonal order) after $\mathrm{Ag}^{+}$doping especially for the samples MSP2 and MSP4. Both the samples were indexed as (100), (110), (200) and no shift in peak positions was observed after doping. For MSP1, marginal peak shifting in the diffractogram was observed after $\mathrm{Ag}^{+}$doping (Fig. 3a inset), the peak shift could be due to some degree of distortion in pore structure during $\mathrm{Ag}^{+}$doping process in aqueous media, while no peak shift was observed for MSP2 and MSP4 samples after $\mathrm{Ag}^{+}$doping (Inset Fig. 3b and Fig. 3c). The absence of significant peak shifts in the diffractogram patterns of Fig. 3 and insets also prove that calcination of MSPs after the synthesis of MSPs provides sufficient rigidity and prevents the destruction of pore structure and particle morphology. ${ }^{30,31}$
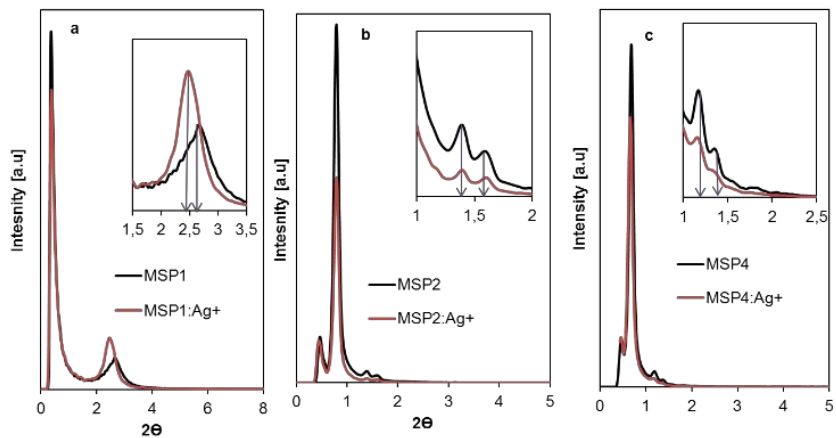

Fig. 3. Powder X-ray diffraction patterns of a) MSP1 b) MSP2 and c) MSP4 and their corresponding $\mathrm{Ag}^{+}$doped counterpart.

The $\zeta$-potential values of the particles in aqueous solvent (10 $\mathrm{mM}$ acetate buffer at $\mathrm{pH} 5$, concentration $0.25 \mathrm{mg} / \mathrm{mL}$ ) were measured after each consecutive synthesis steps. The changes in the values before and after modification of MSPs indicate the success of both $\mathrm{Ag}^{+}$doping and chitosan adsorption on MSPs (Table 1). The observed decrease in the negative $\zeta$-potential values after $\mathrm{Ag}^{+}$doping is probably due to the accumulation of positively charged silver ions on the MSPs which result in less net negative surface charge compared to pristine MSPs. The accompanied amount of chitosan on MSPs: $\mathrm{Ag}^{+}$samples were further determined by thermogravimetric analysis (TGA) as presented in the Fig. S5. The extent of chitosan on the samples were estimated as $3 \mathrm{w} / \mathrm{w} \%, 6 \mathrm{w} / \mathrm{w} \%$ and $6 \mathrm{w} / \mathrm{w} \%$ for $\mathrm{Cht} / \mathrm{MSP} 1: \mathrm{Ag}^{+}, \mathrm{Cht} / \mathrm{MSP} 2: \mathrm{Ag}^{+}, \mathrm{Cht} / \mathrm{MSP} 4: \mathrm{Ag}^{+}$, respectively.

Table1. Z-potential values of prepared MSP suspensions before and after $\mathrm{Ag}^{+}$doping and chitosan coating.

\begin{tabular}{lc}
\hline \multicolumn{1}{c}{ Sample Name } & $\begin{array}{c}\text { Zeta } \\
\text { Potential } \\
\text { [mV] }\end{array}$ \\
\hline MSP1 & \\
MSP2 & $-33 \pm 0.6$ \\
MSP4 & $-19 \pm 0.1$ \\
MSP1:Ag & $-24 \pm 1.4$ \\
MSP2:Ag & $-20 \pm 0.8$ \\
MSP4:Ag & $-10 \pm 0.3$ \\
Cht/MSP1: & $-12 \pm 0.1$ \\
Cht/MSP2: $\mathrm{Ag}^{+}$ & $37 \pm 0.6$ \\
Cht/MSP4: $\mathrm{Ag}^{+}$ & $36 \pm 0.5$ \\
\end{tabular}

In order to investigate any instance of chitosan desorption from the particles surfaces isothermal microcalorimeter instruments were employed. Thermal changes of chitosan coated MSPs was tracked for $6 \mathrm{~h}$ in $25 \mathrm{mM}$ HEPES buffer (pH7.2, $36.5^{\circ} \mathrm{C}$ ). Fig. $\mathrm{S} 6$ shows that no critical thermal changes occur on desorption of chitosan form the MSP surfaces. The small changes possibly come from the reorganization of chitosan polymer on the MSP surface during the analysis time period. A very similar behavior related to the reorganization of copolymers on the silica nanoparticles was also observed in one of our previous study. ${ }^{32}$ Moreover, we checked the $\zeta$-Potential of chitosan coated MSPs over a day, we didn't notice any significant changes in the $\zeta$-potential values. To the best our knowledge, once the physical adsorption of macromolecules (such proteins, polymers) occurs on the particles surfaces, they are difficult to release without harsh $\mathrm{pH}$ changes of the environment or strong mechanical treatments. For instance, Casals et al ${ }^{33}$ have shown that when the serum proteins are adsorbed on the surface of negatively charged metal oxide nanoparticles they can remain stable for days in water. These results certainly confirm no desorption of chitosan from the surface of MSPs.

The extent of doped $\mathrm{Ag}^{+}$on MSPs was determined by AAS. According to AAS results 1.3, $0.5,0.4 \mathrm{w} / \mathrm{w} \% \mathrm{Ag}^{+}$was accumulated on MSP1: $\mathrm{Ag}^{+}, \mathrm{MSP} 2: \mathrm{Ag}^{+}$and MSP4:Ag+ samples respectively. The release profiles of silver ion from the prepared MSPs were determined by ICP-AES analysis and presented in Fig. 4. The data clearly showed the higher release of $\mathrm{Ag}^{+}$from the uncoated MSP compared to chitosan-coated samples. 


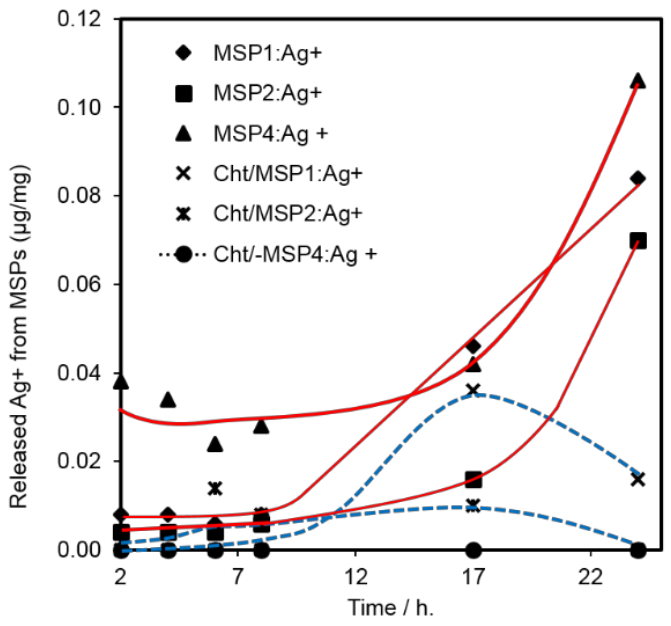

Fig. 4 Silver ion release profile from MSPs over time.

\section{Effect of MSPs size, shape and surface modifications on bacterial growth}

The growth of three different bacterial strains, two Gramnegative (E.coli and $V$. cholerae) and one Gram-positive (S. aureus), were examined in the presence of MSPs of different size, shape, and surface coating. The growth inhibition was measured after $4 \mathrm{~h}$ of MSPs incubation (Fig. 5). From the preliminary screen, it was clear that pristine MSPs have weak antimicrobial potential. The antimicrobial activity of MSPs can be modulated (enhanced) either by doping with $\mathrm{Ag}^{+}$and chitosan or by simultaneous modification with both the agents (to achieve maximum inhibition). The screening data also shows that (Cht/MSP1:Ag+, Cht/MSP2:Ag ${ }^{+}$Cht/MSP4:Ag+) samples possess good antibacterial activity against all three tested bacteria.

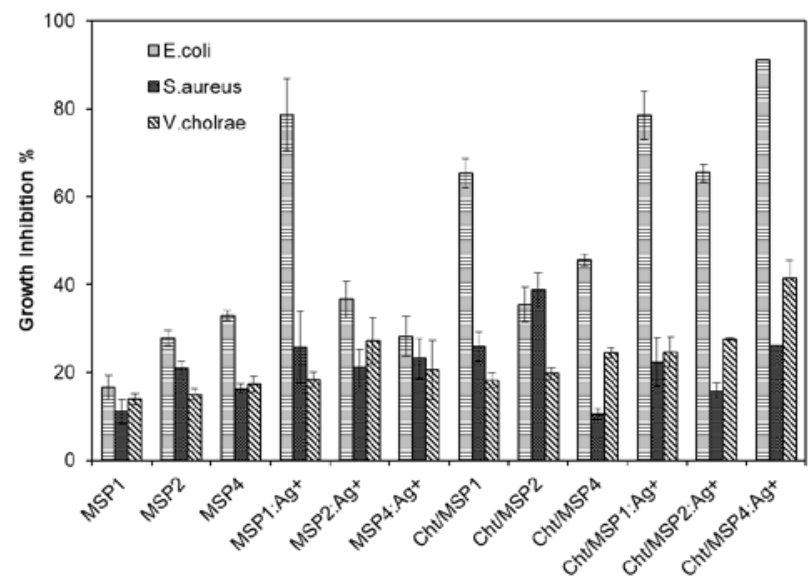

Fig. 5. Percentage growth inhibition of three bacterial strains after their exposure to different MSP (concentration of $50 \mu \mathrm{g} / \mathrm{ml}$ ) for $4 \mathrm{~h}$ Results are represented as mean \pm SD. P values in all calculation's $<0.001$.

The three most potent antibacterial samples were further subjected to time-dependent growth inhibition assays, and it was found that Cht/MSP4:Ag+ has the highest antimicrobial potential against all three test organisms (Fig. 6a,6b,6c). It was also noticed that Cht/MSP4:Ag is most active against E.coli (killing was almost $100 \%$ ) and least effective against V.Cholerae.
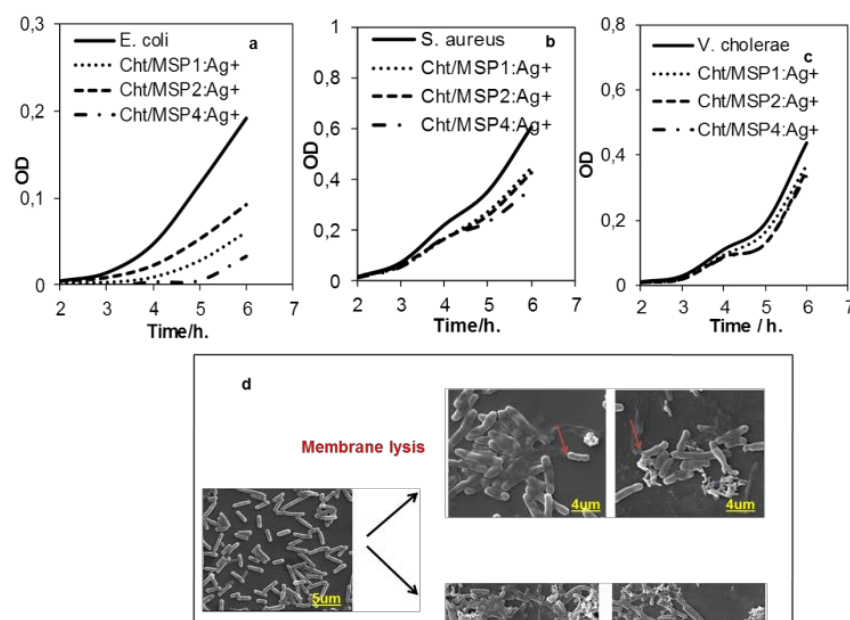

Cell elongation
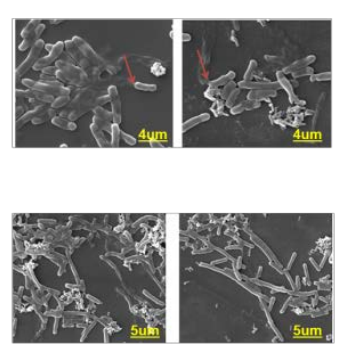

Fig. 6. Antimicrobial effects of the most potent antibacterial MSPs on the growth kinetics of different bacteria, a) E. coli, b) S. aureus and c) $V$. cholerae. The effective dose of NP is $50 \mu \mathrm{g} / \mathrm{mL}$ in all experiments. d) Scanning electron microscopic images of $E$. coli cells in the presence of

Cht/MSP4:Ag+; the untreated cells (control) are shown on the left.

Additionally, we calculated the minimum inhibitory concentration (MIC), and it was found to be $200 \mu \mathrm{g} / \mathrm{mL}$ for Cht/MSP4:Ag+ against all the tested strains (data not shown). Interestingly, a steady increase of OD (optical density) with time was also noticed in all the MSP-treated bacterial samples in all the growth kinetics experiments. To visualize the phenotypic changes of the cells grown in the presence of MSPs, we have performed detailed SEM analyzes of all our samples. Enlargement by almost ten-fold in E. coli and four-fold in $V$. cholerae size have been observed from SEM analysis (Fig. 6d). Furthermore, we performed a statistical analysis on a number of elongated cell versus normal cells and our result showed that cell elongation was a much more prominent event in $E$. coli compared to $V$. cholerae (Table S2). An earlier work by Chatterjee et al. has also showed E.coli cell filamentation on copper nanoparticle treatment. ${ }^{34}$ They also suggested that bacterial filamentation positively influences the optical density of the culture, which corroborates well with our observation. The SEM images have also depicted severe membrane damage and consequent leakage of intracellular protein. To validate the interpretation of OD-based data, dilution plating on LB agar plates was done. Reduction in the number of colonies in plates confirms (Fig. S7) that our synthesized nanoparticles have an appreciable degree of antibacterial potential. The most striking SEM observation was the transformation of the majority of bacterial cells into filaments (elongated cells) in the presence of MSPs. Filamentation in bacteria can be induced and was known to be one of the defense mechanisms to protect themselves from environmental stress and killing conditions. Earlier results 
have shown that the bacterial cell elongation took place on treatment by fluoroquinolone class of antibiotics. ${ }^{35,36}$ These antibiotics function by preventing cell division mainly by interfering with bacterial chromosome segregation and as an outcome, cells grow abnormally without any division, resulting in elongation of the cell. One of the key protein that is responsible for bacterial cell division is FtsZ. Impairments of its function frequently lead to cell elongation, and eventually filamentous structure formation. ${ }^{37,38}$ We believe that there was a direct crosstalk between FtsZ and Cht/MSP4:Ag+. Also, it has been reported that treatment of the bacterial cells with $\mathrm{Cu}$ and CdO nanoparticles leads to cell elongation, and the authors have speculated that direct interaction of FtsZ with nanoparticles lead to such a phenotypic alteration in bacteria. ${ }^{34,39}$

\section{Bacteriolytic effect of Cht/MSP4:Ag}

SEM data have elucidated severe compromises in the usual plasticity of the bacterial membrane during treatment with MSPs, similar to observations made by earlier authors on treating bacteria with other nanoparticles. ${ }^{40,41}$ Membrane plays a vital role in microbial defense, and here we have made a systematic investigation of its structural change upon MSP treatment. Membrane potential being a very sensitive indicator of membrane integrity change and a fluorescence anisotropy based assay was used ${ }^{42}$ to monitor the change in membrane potential due to MSPs treatment. As expected, a considerable change in membrane polarization has been observed in the treated E.coli bacterial sample (Fig. 7a), supporting the MSPinduced phenotypic changes (membrane perturbation) of the cells as observed by SEM (Fig. 6d).

The most likely effect of membrane damage is the leakage of the cytoplasmic protein. We quantified the extent of protein leakage in the Cht/MSP4:Ag+treated bacteria with respect to the untreated control. There was almost $50 \%$ increase in protein leakage from the treated $E$. coli cells, $\sim 10 \%$ effect on $S$. aureus, and negligible effect was observed against $V$. cholerae (Fig. 7b). This is in conformity with the differences in the results of growth kinetics of the three bacteria in the presence of MSPs (Fig. 6a, 6b, 6c).
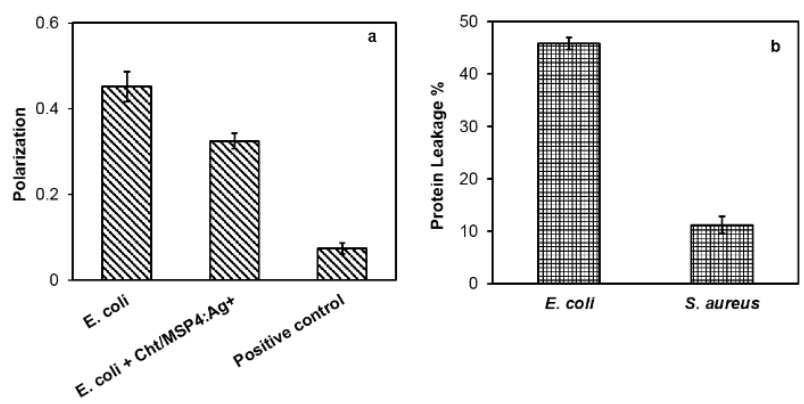

Fig. 7. a) Change in membrane fluidity of $E$. coli cell on Cht/MSP4:Ag+ treatment measured using fluorescence anisotropy. Results are represented as mean \pm SD. P value $<0.005$. b) Protein leakage (in \%) from E. coli and S.aureus cells on Cht/MSP4: $\mathrm{Ag}^{+}$treatment. $\mathrm{P}<0.002$
Phenomenon of DNA condensation in MSP treated bacterial cells: quantification by FACS

Bacterial DNA does not have a proper enveloped structure; consequently, it is often a soft target of the intruder xenobiotic or some natural small molecules. Earlier, Kumar et al. have found extensive nuclear fragmentation of $E$. coli DNA in the presence of $\mathrm{ZnO}$ nanoparticles using confocal fluorescence microscopy. ${ }^{43}$ In a separate study, Premanathan et al. also made a similar kind of observation. ${ }^{44}$ Our group has also reported extensive DNA degradation of several different multidrug resistant bacteria when they were treated with $\mathrm{ZnO}$ NPs. ${ }^{27}$ We quantified the extent of DNA damage (if any) caused by the MSPs, using a FACS based assay. The present study gave result that was dramatically opposite with respect to our earlier observation and therfore appear to be quite intriguing. DAPI is used here as a DNA binding probe; normally DAPI fluorescence decreases on DNA fragmentation, and the opposite is the case when DNA condensation takes place. In our earlier experiments with ZnO-NP treated bacteria, DAPI fluorescence decreased due to extensive DNA fragmentation. ${ }^{27}$ In contrast, the DNA fluorescence intensity increased in the presence of the MSP (Fig. 8). In the previous section we discusses that upon Cht/MSP4: $\mathrm{Ag}^{+}$treatment normal bacterial cell division process gets halted (bacteria stopped responding to binary fission) and forms giant elongated filament-like structures (Fig. 6d). When translocation of the newly replicated DNA strands into the daughter cells is prevented or if there is a failure of replication retaining the super-coiled condensed parental chromosomal DNA of the cells in nutritional abundance, cells tend to be characteristically elongated. Under such circumstances, DAPI fluorescence will be opposite to the conditions noted in the cells having fragmented DNA. This phenomenon of increased DAPI fluorescence, although not very common, has been seen before in bacteria with other antimicrobial agents. ${ }^{45}$
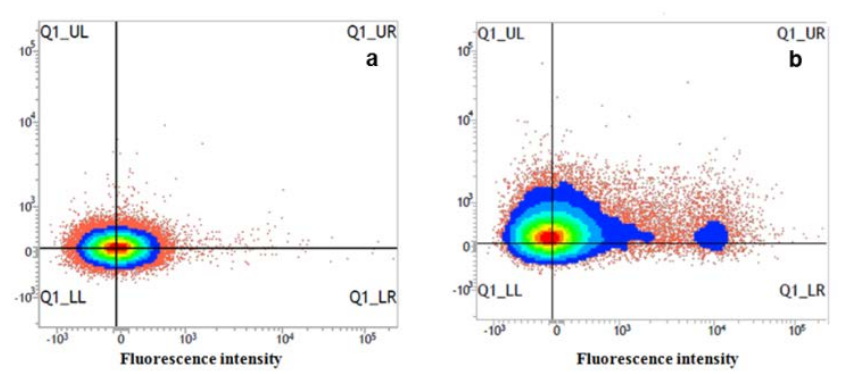

Fig. 8. Flow cytometric analysis of DNA content of (a) E. coli cells alone (control) and (b) in presence of Cht/MSP4:Ag+ by using DAPI dye.

\section{Synergistic or additive bactericidal effect of MSPs with kanamycin}

One of our earlier studies with $\mathrm{ZnO}-\mathrm{NP}$ showed that when an antibiotic or NP alone was supplemented to the bacterial growth medium, it resulted only in moderate killing, ${ }^{27,41}$ while the killing activity increased significantly if they are administered together, indicating synergism. The rationale behind this phenomenon is rather straightforward: internalization of NP accompanied with membrane rupture of the bacterial cell may further lead to the inactivation of efflux 
pumps, resulting in accumulation of antibiotics. Recently, Lowrence Rene et al. have shown that NPs can effectively inhibit membrane-bound efflux pumps (which are mostly responsible for pumping out antibiotics). ${ }^{46}$ Once the membrane gets compromised, more antibiotic influx is possible within bacteria. Our result showed that $\mathrm{Cht} / \mathrm{MSP} 4: \mathrm{Ag}^{+}$is most effective against E.coli and moderately effective against the two other microorganisms, including V.cholerae (Fig. 6a,6b,6c). Since the toxicologically safe concentration of Cht/MSPs (1/2/4): $\mathrm{Ag}^{+}(50$ $\mu \mathrm{g} / \mathrm{mL}$ ) has only moderate anti-bacterial effect against $V$.cholerae, we examined if the effect could be augmented by co-administration with antibiotics. For this purpose, V.cholerae cell was incubated with $50 \mu \mathrm{g} / \mathrm{mL} \mathrm{Cht} / \operatorname{MSPs}(1 / 2 / 4): \mathrm{Ag}^{+}$in combination with $5 \mu \mathrm{g} / \mathrm{mL}$ kanamycin (antibiotic). The results showed that either Cht/MSPs (1/2/4): $\mathrm{Ag}^{+}$or kanamycin (antibiotic) alone is inefficient in eradicating V.cholerae completely, but interestingly, when they are administered together, the effect is increased notably (Fig. 9a and 9b).

Literature studies confirmed the presence of a good number of efflux pumps in V.cholerae membrane; ${ }^{47}$ as a possible outcome, the entry of the antibiotic was either inhibited or pumped out by these efflux proteins. Our hypothesis is that on treatment with Cht/MSPs: $\mathrm{Ag}^{+}$disruption of the cell membrane may lead to the inactivation of the efflux pump, resulting in accumulation of higher amounts of kanamycin inside bacteria. Intracellular kanamycin may thereby bind to its target, which it failed in cells not treated with Cht/MSPs: $\mathrm{Ag}^{+}$. Ceasing of protein synthesis coupled with membrane damage may have contributed to this synergism.

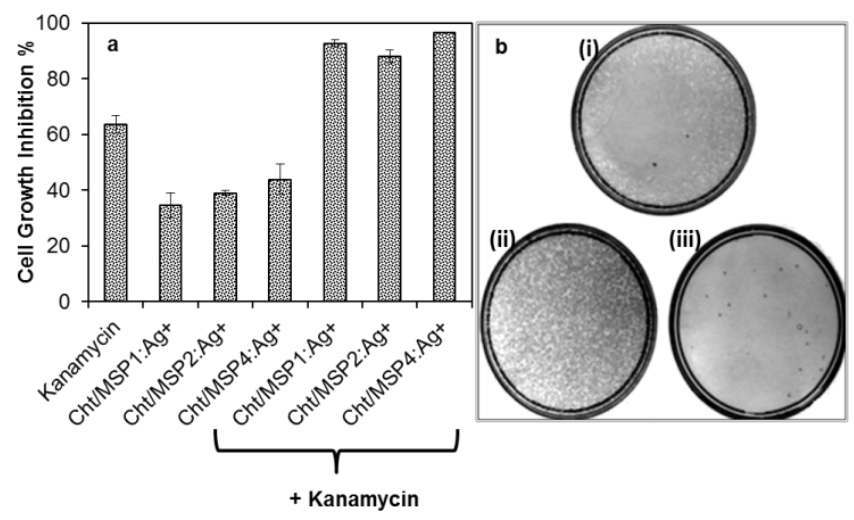

Fig. 9. a) Synergistic effect of MSPs and kanamycin against $V$. cholerae MSPs $(40 \mu \mathrm{g} / \mathrm{mL})$ and kanamycin $(5 \mu \mathrm{g} / \mathrm{mL})$, either incubated alone or in different combinations with bacteria. Error bars represent standard deviation. Results are represented as mean \pm SD. $P$ value ranging between 0.02 and 0.001 . b) The growth of V.cholerae cell in LB agar plate (i) in the presence of Cht/MSP4: $\mathrm{Ag}^{+}$but in the absence of kanamycin (ii) in the absence of Cht/MSP4: $\mathrm{Ag}^{+}$and kanamycin (iii) combination of Cht/MSP4: $\mathrm{Ag}^{+}$and kanamycin.

\section{In-vitro cytocompatibility of MSPs}

Viability of Caco- 2 cells incubated with increasing concentration $\left(25,50\right.$ and $100 \mu \mathrm{g} / \mathrm{ml}$ ) of MSPs (Cht/MSP1:Ag ${ }^{+}$Cht/MSP2: $\mathrm{Ag}^{+}$
Cht/MSP4:Ag+) were checked at $24 \mathrm{~h}$ time period by WST-1 assay (Fig. 10).

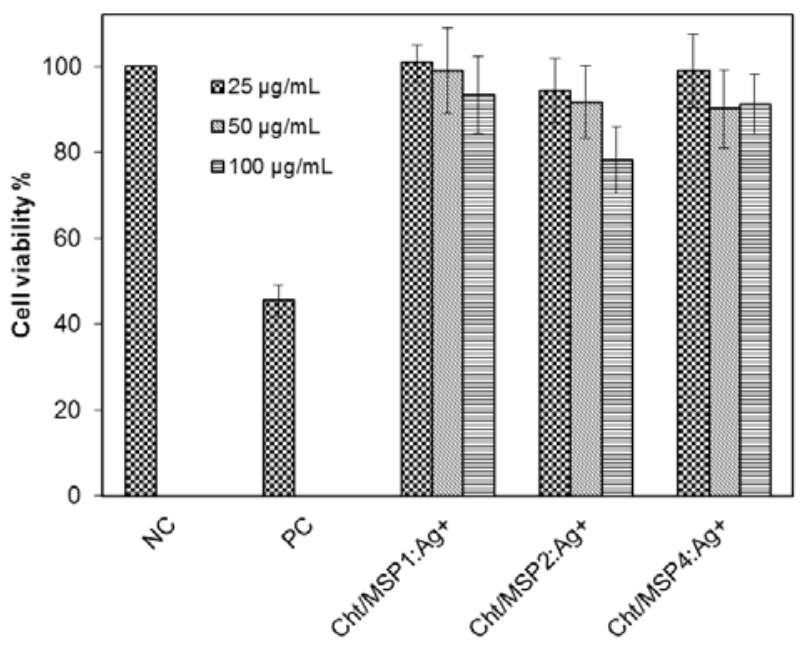

Fig. 10. In-vitro dose-dependent cell viability of Caco-2 cells against Cht/MSP1:Ag ${ }^{+}, \mathrm{Cht} / \mathrm{MSP} 2: \mathrm{Ag}^{+}, \mathrm{Cht} / \mathrm{MSP} 4: \mathrm{Ag}^{+}$samples after $24 \mathrm{~h}$. Results are represented as mean $\pm \mathrm{SD}$. ${ }^{*} \mathrm{P}<0.05$

The results were promising, all three samples were found cytocompatible (Cht/MSP 1:Ag+, Cht/MSP 2:Ag+, Cht/MSP $4: \mathrm{Ag}^{+}$) when the dose levels were kept below $50 \mu \mathrm{g} / \mathrm{mL}$. The bacterial killing experiments were set up in a timescale of $12 \mathrm{~h}$ maximum, and according to our results, all the MSPs are safe in that small-scale window.

\section{Discussion}

In last two decades, several studies have reported antibacterial activities of different nanoparticles. ${ }^{9,10}$ However, most of these studies were devoid of providing a plausible mechanism of actions. There are many open questions that need to be answered before materializing them for clinical purposes. The first concern associated with most of the NP is their poor dispersibility in water. ${ }^{48}$ It has been found that almost all metal and metal oxide nanoparticles, including colloidal silver and $\mathrm{ZnO}$, which show excellent antimicrobial properties, are very poorly dispersible in water and physiological buffers. ${ }^{49}$ The second growing concern is their non-specific toxicity towards healthy human cells. ${ }^{50}$ In fact, during the last decade, the research in antimicrobial nanoparticles have been mostly focused towards silver NPs; unfortunately, all recent studies clearly showed that colloidal silver NPs were highly toxic towards normal human cells. ${ }^{51}$ The concept of utilizing silica NPs as an antimicrobial agent is comparatively new, as the focus has now been shifted towards making non-toxic, safe nanoparticles. ${ }^{52}$ Recently, in two studies, diffrent design of silica nanoparticles has been found effective in killing bacterial cells without damaging human cells. ${ }^{53,54}$ Tank et al. found that silica coated silicon nanotubes have excellent antimicrobial activity against both Gram-positive and Gram-negative bacteria. ${ }^{52}$ In a separate study, Song et al. also showed the antimicrobial effect 
of silver-doped silica nanoparticles against several test microorganisms. ${ }^{54}$ Another characteristic feature of silica NP makes them popular is their dispersibility in the aqueous media; a property which most of the nanoparticles lack. ${ }^{55}$ There is no doubt that MSPs have great potential in the field of antibacterial nanomedicine, but the bottleneck is insufficient mechanistic studies on how MSP kills bacteria. In addition, there has been no systematic study available addressing how shape and size variation along with surface engineering could influence antimicrobial properties of MSPs. Earlier studies have showed that shape and size variations have a good impact on the antimicrobial properties of many other nanoparticles. ${ }^{56,57}$

The foundation of this study begins with 1) How do the shape and engineering of MSPs surface influence the antimicrobial potential? and, 2) How do MSPs kill (mechanism of action) bacteria?

To address these questions, we synthesized differently shaped mesoporous silica nanoparticles (Fig. S1 and Fig. S3) and we further modified them by doping with silver and chitosan. Afterward, the synthesized sample series were tested against a number of bacterial species (both Gram-negative and Grampositive) (Fig. 5). Results clearly demonstrated that most of our synthesized MSPs have antimicrobial potential, and with increased aspect ratio an enhancement in bacterial killing (E.coli) was also noticed.

NP exerts antimicrobial action mostly by damaging bacterial membrane. Our results showed that bacterial membrane gets compromised on MSP treatment (Fig. 6d). The question is how MSPs get attached to the bacterial cell wall and damaged the bacteria; Gram-negative bacterial cell wall is composed of lipopolysaccharides (outer membrane), phospholipids and transmembrane proteins, with an underlying peptidoglycan layer. MSPs interact with the bacterial membrane by forming hydrogen bonds between lipopolysaccharides of bacterial cell wall and surface hydroxyl groups present in MSPs. Previously Capeletti et al. showed the interaction between silica NP and lipopolysaccharides membrane of bacteria through hydrogen bonding, they also found that under shaking condition probability of interactions get increased. ${ }^{58}$ They even claimed that constant shaking helps MSP to reach and destabilize the peptidoglycan layer. In other systems also, it has been demonstrated that this behavior is related to hydroxyl groups. ${ }^{59,60}$ We presume that the disruption of the bacterial outer membrane is one of the important pathways by which MSPs cause damage. However, we are not ruling out other possibilities of membrane damage by MSP, such as the chemical damage to membrane biomolecules, robbing of lipid molecules through adsorption onto NPs, or membrane gelation/ fluidization after nanoparticle attachment.

Among all the MSPs, Cht/MSP4: $\mathrm{Ag}^{+}$showed the maximal antimicrobial potential against all tested bacteria. Interestingly, this particular design of NPs also has the highest aspect ratio $(A R=4)$ and chitosan coating (Fig. S1, Fig.S5). It has been shown earlier that NPs with high aspect ratio aligns their long axis parallel to the cell membrane, and this normally leads to higher rate of membrane attachment (as it covers large surface) and more destruction of bacterial membrane compared to NPs with lower aspect ratios. ${ }^{57}$ In support of our data, it could be easily speculated that MSPs with high aspect ratio may cause increased cell membrane attachment and eventually more bacterial membrane disruption compared to those with lower aspect ratios (Fig. 5).

According to our findings, the effect of each parameter on antibacterial actibity is not straightforward .For instance, the shape effect is obvious with the bare particles (Fig. 5), thus with the increased aspect ratio of MSPs growth inhibition is increased.However, this effect gets masked when $\mathrm{Ag}^{+}$is doped on the particles surface. The observed antibacterial effect is related to the extent of $\mathrm{Ag}^{+}$ion adsorbed on MSPs matrix in this case. MSP1 with the highest $\mathrm{Ag}^{+}$extent is found most effective in killing E.coli and the effect reduces with the decrease in $\mathrm{Ag}^{+}$ extent. The effect of MSP shape on the bacterial growth inhibition also obscured when there is only chitosan coating on MSPs. We believe the observed antimicrobial effect is associated with the conformation of existing chitosan polymer on the particles. For a long time, chitosan, has been used as either bactericidal (kills the live bacteria) or bacteriostatic (hinders the growth of bacteria) agent. ${ }^{61}$ The most common mechanism of chitosan action is the electrostatic interaction of positively charged chitosan molecules with negatively charged microbial cell wall/membrane. Raafat et al. have demonstrated the effect of positively charged chitosan on Staphylococcus simulans cell and the corresponding structural change. ${ }^{62}$ They have shown direct attachment of chitosan molecules on the bacteria cell wall with the help of powerful transmission electron microscope. They have also found that the interacting site of the cell membrane became locally detached from the cell wall and as an outcome water and ion efflux were generated, resulting a membrane lysis.

When the MSPs design is fulfilled by both $\mathrm{Ag}^{+}$doping and chitosan coating (Cht/MSPs:Ag+), the observed antibacterial activity is no more related to the extent of $\mathrm{Ag}^{+}$and chitosan coating over MSPs. Rather in such circumstances, antibacterial effect of MSPs depends on metal chelating properties of chitosan. In the literature, antibacterial properties of chitosan was investigated as chitosan-metal complexes and compared with free chitosan and metal salts. As described in the study of Wang et al. during complexion reaction between chitosan and metal ions, metal ions act as acceptor of electrons "super acid". ${ }^{63}$ The positive charge density of chitosan increases after chelating with metal ions, which subsequently leads to enhancement in adsorption of polycationic chitosan onto the negatively charged cell surface and as a result better antimicrobial activity of chitosan-metal complex was observed compared to chitosan itself. In the same study, the reason for not getting similar inhibitory effect against different microorganisms was assigned to differences of negative charge distribution on the cell surfaces of microorganisms. Here also we found expected trend in antimicrobial activity of chitosan coated and silver doped samples compared to the only chitosan coated samples, as metal-chitosan complexation is only possible in the former case.

We have also noticed that with increasing time interval there was a steady decrease in bacteria killing by MSP (Fig. 6) 
which was observed with the increase of OD in time. This phenomenon may happen due to two reasons; first, with time it is highly possible that effective MSP concentration gets lowered as they were more exposed to bacterial debris, which may cause precipitation of MSP. Infact, in an earlier report, Sondi et al found a similar kind of phenomenon with silver nanoparticles, and they suggested that particles after few hours of incubation with bacterial cells get encapsulated by bacterial debris (protein debris) due to cell lysis, which inhibits particles to effectively interact with the bacterial cell membrane. ${ }^{64}$ The second probable reason is that in the presence of MSP, a considerable amount of bacterial cells get elongated (due to problems in cell division) and this may be attributed to an increase in the scattering intensity as the turbidity of the medium gets changed.

SEM images suggest that there was almost 2-10 fold increase in the bacteria cell length (elongation) on MSP treatment (Fig. 6d and Table S2). Bacterial cell elongation on nanoparticle treatment has been reported with $\mathrm{CdS}, \mathrm{CdO}, \mathrm{Cu} \mathrm{NP}$ and cell elongation in the presence of CdS was directly correlated with down-regulation of FtsZ expression. ${ }^{27,34,39}$ FtsZ plays a vital role in septum formation in dividing bacteria by interacting with other division proteins. ${ }^{37,38}$ The evidence also suggests that changes in FtsZ expression levels or its impairment of function (mostly because of unfolding and depolymerization) under stress interfered with cell division, thus causing multinucleated filamentous structures of bacterial cells. ${ }^{65} \mathrm{In}$ our experiments, most likely cause of cell elongation was exposure of FtsZ to either chitosan or other fragments of MSP. Investigations are ongoing in our laboratory to study how MSPs binds and down regulates FtsZ. FACS data also suggest that either there is an abnormal increase of DNA content or high degree of DNA condensation occurs due to failure in the replication coupling to the cell division process (Fig. 8), which further supports our hypothesis that MSPs impaired the cell division process (possibly by interacting with FtsZ) in bacterial cells.

Cht/MSP4:Ag ${ }^{+}$was found to be most effective against E.coli and least effective against $V$. cholerae, (Fig. 6 ) and it was most probably because of the difference in membrane architecture of these two bacteria. The constitution of the membrane was also found to be responsible for the differential behavior of two biotypes of V. cholera towards $\mathrm{ZnO}$ nanaoparticles. ${ }^{66}$ It is known that $V$. cholerae can remodel their membrane architecture frequently just by utilizing exogenous lipids from the environment. ${ }^{67}$ This is one of the principle mechanisms (membrane remodeling) through which $V$. cholerae minimize membrane stress caused by external environment. Though most of the Gram-negative bacteria do exchange lipids with the membrane, the membrane remodeling process in $V$. Cholerae happened in a much faster and efficient manner compared to any other Gram-negative bacteria; and that certainly helps them to survive in extreme conditions. Our opinion is that due to their highly fluidic membrane architecture, they can withstand much higher MSPs concentration.

To make Cht/MSP4: $\mathrm{Ag}^{+}$more effective, we have also attempted a combinatorial therapy with antibiotic kanamycin against V.cholerae cells, and we found that this approach was more effective than individual nanoparticle treatment (Fig 9). We rationalize this assumption that upon MSP treatment, the bacterial membrane gets leaky and loses resistance towards antibiotics, and as an outcome antibiotics get easy access to the cytosol causing inhibition to protein synthesis and, ultimately, to cell death. We believed that this is the first study where we systematically showed how one could render (by changing shape and surface coating) the design of MSPs to make them effective against bacteria.

\section{Conclusions}

This study shows the molecular basis of antimicrobial action of silica NP against both Gram-negative and Gram-positive bacteria. We found that shape and surface chemistry are two vital parameters that actually govern the antimicrobial property of mesoporous silica nanoparticles. Cht/MSP4: $\mathrm{Ag}^{+}$, which has the highest aspect ratio and decent silver and chitosan coating, was found to be most effective among all the MSPs. Our results further indicate that upon interaction with the MSPs, damage in the bacterial membrane was prevalent, resulting in intracellular protein leakage. Furthermore, we found cell filamentation on the treatment of MSPs, which most likely occurs due to the impairment of FtsZ function. Finally, synergistic antibacterial effects were noted when MSP used in combination with kanamycin against $V$. cholerae. Hence, this study provides novel insight into the antimicrobial potency of mesoporous silica nanoparticles, which hold promise for the development of next generation nanobiotics with non-toxic nature and flexible design options.

\section{Acknowledgements}

The authors would like to acknowledge Linus Silvander for SEM imaging, Sten Lindholm for ICP-AES analysis. S.S thankfully acknowledge fellowship from CSIR, India. P.C is recipient of J.C. Bose national fellowship. We are also thankful to $\mathrm{Dr}$. $\mathrm{R}$ Chakraborty (NBU, India) for his helpful suggestion and proof reading.

\section{References}

1 World Health Organization, ed., Global Health Risks: Mortality and Burden of Disease Attributable to Selected Major Risks (Geneva, Switzerland: World Health Organization, 2009).

2 J. Olivares, B. Alejandra, G.-L. Guillermo, C. Fernando, B. S. Maria, L. M. Jose, Frontiers in Microbiology, 2013, 4.

3 P. A. William, M. Miller, H. J. Binder, M. M. Levine, R. Dillingham, R. L. Guerrant, Journal of Clinical Investigation, 2008, 118, 1277.

4 S. M. Faruque, M. J. Albert, J. J. Mekalanos, Microbiology and Molecular Biology Reviews: MMBR, 1998, 62, 1301.

5 Weekly Epidemiological Record, World Health Organization, 2014, 89, 345.ISSN: 0049-8114.

6 A. J. Huh, Y. J. Kwon, Journal of Controlled Release, 2011, 156, 128.

7 L. B. Rice, Current Opinion in Microbiology, 2009, 12, 476. 
8 R. Y. Pelgrift, A.J. Friedman, Advanced Drug Delivery Reviews, 2013, 65, 1803.

9 T. J. Webster, I. Seil, International Journal of Nanomedicine, 2012, 7, 2767.

10 L. Zhang, D. Pornpattananangku, J .Hu ; C.-M Huang, Current Medicinal Chemistry, 2010, 17, 585

11 T. Fangqiong, L. Linlin, C., Advanced Materials, 2012, 24, 1504.

12 H. Qianjun, S. Jianlin, Journal of Materials Chemistry, 2011, 21, 5845.

13 A. J. Sushilkumar, Inorg. Chem. Front., 2014, 1, 735.

14 L. Canham, H. A. Santos, G. Palestino, Mesoporous Biomaterials, 2015, 2.

15 T. Maldiney, B. Benoit, M. Bessodes, D. Scherman, R. Cyrille, Nanoscale, 2014, 6, 13970.

16 F. Tang, L. Li, D. Chen, Advanced Materials, 2012, 24, 1504.

17 S. Bhattacharyya, H. Wang, P. Ducheyne, Acta Biomaterialia. $2012,8,3429$

18 L. M. Jurkić, I. Cepanec, S. K. Pavelić, Pavelić K., Nutrition \& Metabolism. 2013, 10.

19 M. Sajid, M. llyas, C. Basheer, M. Tariq, M. Daud, N. Baig, F. Shehzad, Environmental Science and Pollution Research, 2015, 22, 4122 .

20 J. Song, K. Hyunyoung, J. Yoonsun J. Jyongsik, ACS Applied Materials \& Interfaces 2013, 5, 11563.

21 K. Hotta, H. Yamamoto, Y. Okami, H. Umezawa, The Journal of Antibiotics, 1981, 34, 1175.

22 G. J. Alangaden, B.N. Kreiswirth, A. Aouad, M. Khetarpal, F. R. Igno, S. L. Moghazeh, K. Elias, E. K. Manavathu, S. A Lerner, Antimicrob. Agents Chemother., 1998, 42, 1295.

23 E. M. Björk, F. Söderlind, M. Odén, Langmuir, 2013, 29, 13551.

24 E. M. Johansson, A. B. Mohamed J. M. Córdoba, M. Odén, Langmuir, 2011, 27, 4994.

25 R. Iler, The Chemistry of Silica: Solubility, Polymerization, Colloid and Surface Properties and Biochemistry of Silica (New York: John Wiley and Sons, 1979).

26 C. A. Schneider, W. S Rasband, K. W Eliceiri, Nature Methods, 2012, 9, 671.

27 S. Chakraborti, A. K. Mandal, S. Sarwar, P. Singh, R. Chakraborty, P. Chakrabarti, Colloids and Surfaces B: Biointerfaces, 2014, 121, 44

28 V. Meunier, M. Bourrie, Y. Berger, G. Fabre, Cell Biology and Toxicology, 1995, 11, 187.

29 R. Senthilkumar, D. Sen Karaman, P. Paul, E. M. Björk, M. Oden, J. E. Eriksson, J. M. Rosenholm, Biomaterials Science, 2015, 3,103.

30 D. Desai, D. Sen Karaman, N. Prabhakar, S. Tadayon, A. Duchanoy, D.M. Toivola, S. Rajput, T. Näreoja, J. M. Rosenholm, Mesoporous Biomaterials, 2014, 1.

31 D. Şen Karaman, D. Desai, J. Zhang, S.Tadayon, G. Unal, J. Teuho, J. Sarfraz, J.-H. Smått,H. Gu, T. Näreoja, J.M. Rosenholm, Journal of Materials Chemistry B, 2016,4, 1720.

32 D. Sen Karaman, T. Gulin-Sarfraz, G. Hedström, A. Duchanoy, P. Eklund, J.M. Rosenholm, Journal of Colloid and Interface Science, 2014, 418, 300.

33 E. Casals, T. Pfaller, A. Duschl, G. J. Oostingh, V. F. Puntes, Small, 2011, 7, 3479.

34 A. K. Chatterjee, R. K. Sarkar, A. P. Chattopadhyay, P. Aich, R. Chakraborty, T. Basu, Nanotechnology, 2012, 23.

35 D. R. Korber, G. A. James, J. W. Costerton, Applied and Environmental Microbiolgy, 1994, 60, 1663.

$36 \mathrm{~J}$. Zahller, P. S. Stewart, Antimicrobial Agents and Chemotherapy, 2002, 46, 2679.

37 A. W. Bission-Filho, K. F. Discola, P. Castellen, V. Blasios, A. Martins, M. L. Sforça, W. Garcia, Proceedings of the National Academy of Sciences, 2015, 112, 2130.

38 P. Sass, M. Josten, K. Famulla, G. Schiffer, H.-G. Sahl, L. Hamoen, H. Brotz-Oesterhelt, Proceedings of the National Academy of Sciences, 2011, 108, 17474.
39 S. T. Hossain S. K. Mukherjee, Langmuir, 2012, 28, 16614.

40 E. Taylor, T. J. Webster, International Journal of Nanomedicine, 2011, 6, 1463.

41 S. Chakraborti, S. Bhattacharya, R. Chowdhury, P. Chakrabarti, PLOS ONE, 2013, 8.

42 M. Vincent, L. S. England, J. T. Trevors, Biochimica Et Biophysica Acta, 2004, 1672, 131.

43 A. Kumar, A. K. Pandey, S. Singh, R. Shanker, A. Dhawan, Free Radical Biology and Medicine, 2011, 51, 1872.

44 M. Premanathan, K. Krishnamoorthy, J. Kadarkaraithangam, M. Govindasamy, Nanomedicine: Nanotechnology, Biology and Medicine. 2011, 7, 184

45 L. Fangfei, E. J. Harry, A. L. Bottomley, M. D. Edstein, G. W. Birrell, C. E. Woodward, F. R. Keene, J. Grant Collins, Chem. Sci., 2014, 5, 685

46 C. Lowrence Rene, M. Vimalanathan, P. Prabhakaran, K. B. A Ahmed, I. Bastin, S. Sandhiya, v. Mohan, A. Veerappan, S. Nagarajan, RSC Adv., 2015, 5, 12899.

47 M. F. Varela, S. Kumar, G. He, The Indian Journal of Medical Research, 2013, 138, 285.

48 S. K. Misra, A. Dybowska, D. Berhanu, S. N. Luoma, E. ValsamiJones, Science of The Total Environment, 2012, 438, 225.

49 N. B. Hartmann, C. Engelbrekt, J. Zhang, J. Ulstrup, K. O. Kusk, A. Baun, Nanotoxicology, 2013, 7, 1082.

$50 \mathrm{~W}$. H. De Jong, P. J. A. Borm, International Journal of Nanomedicine, 2008, 3, 133.

51 A. R. Gliga, S. Skoglund, I. Odnevall Wallinder, B. Fadeel, H. L. Karlsson, Particle and Fibre Toxicology. 2014, 11.

52 C. Tank, S. Raman, S. Karan, S. Gosavi, N. P. Lalla, V. Sathe, R. Berndt, W. N. Gade, S.V. Bhoraskar, V.L. Mathe, Journal of Materials Science: Materials in Medicine. 2013, 24, 1483.

53 M. Liong, B. France, K. A. Bradley, J. I. Zink, Advanced Materials, 2009, 21, 1684.

54 J. Song, H. Kim, Y. Jang, J. Jang, ACS Applied Materials \& Interfaces, 2013, 5, 11563.

55 D. Sen Karaman, D. Desai, R. Senthilkumar, E. M. Johansson, N. Råtts, M. Odén, J.E. Eriksson, C. Sahlgren, D. Toivola, J. M. Rosenholm, Nanoscale Research Letters, 2012, 7.

56 M. R. Reithofer, A. Lakshmanan, A.T.K. Ping, J. M. Chin, C. A. E., Biomaterials, 2014, 35, 7535.

57 S. Pal, Y. K. Tak, J. M. Song, Applied and Environmental Microbiology, 2007, 73, 1712.

58 L.B. Capeletti, L.F. de Oliveria, K. de Almeida Goncalves, J.F. A.de Oliveira, A. Saito, J. Kobarg, J.H. Zimnoch dos Santos, M.B. Cardoso, Langmuir, 2014, 30, 7456.

59 A. E. Nel, L. Madler, D. Velegol, T. Xia, E. M. V. Hoek, P. Somasundaran, F. Klaessig, V. Castranova, M. Thompson, Nat. Mater. 2009, 8, 543.

60 I. I. Slowing, C.-W. Wu, J. L. Vivero-Escoto, V. S. Y. Lin, Small 2009, 5, 57.

61 R. C. Goy, D. Britto, O. B. G. Assis, Polímeros: Ciência e Tecnologia, 2009, 19, 241.

62 D. Raafat, K. von Bargen, A. Haas, H. G. Sahl, Applied Environmental Microbiolgy, 2008, 74, 3764.

63 X. Wang, Y. Du, L.Fan, H. Lui, Y. Hu, Polymer Bulletin, 2005, 55, 105.

64 I. Sondi, B. Salopek-Sondi, Journal of Colloid and Interface Science, 2004, 275, 177

65 D. Vinella, M. Cashel, R. D'Ari, Genetics, 2000, 156, 1483.

66 S. Sarwar, S. Chakraborti, S. Bera, I. A. Sheikh, K.M. Hoque, P. Chakrabarti. doi: 10.1016/j.nano.2016.02.006

67 A.C. Pride, C. M. Herrera, Z. Guan, D. K. Giles, mBio, 2013, 4 


\section{Shape engineering boost antibacterial activity of chitosan coated mesoporous silica nanoparticle doped with silver: A mechanistic investigation}

D. Șen Karaman, ${ }^{a, d \#}$ S.Sarwar, ${ }^{b \#}$ D. Desai, ${ }^{a}$ E. M.Björk, ${ }^{c}$ M. Odén, ${ }^{c} P$. Chakrabarti, ${ }^{b}$ J. M.

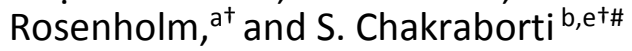

aPharmaceutical Sciences Laboratory, Faculty of Science and Engineering, Åbo Akademi University, Tykistökatu 6A, Turku, FI-20520, Finland, 'bepartment of Biochemistry, Bose Institute, Kolkata 700054, India, 'Nanostructured Materials Division, Department of Physics, Chemistry and Biology, Linköping University, SE-581 83, Sweden, 'Laboratory of Physical Chemistry, Faculty of Science and Engineering, Åbo Akademi University, Porthansgatan 3-5, Turku, FI-20500, Finland. 'Department of Chemistry, Indiana University, Bloomington, Indiana, USA.

Contents of SI:

\begin{tabular}{|c|c|c|}
\hline S. No. & Description & Page \\
\hline & Nomenclature of prepared materials & 2 \\
\hline Fig. S1 & TEM images of MSP1, MSP2, MSP4 & 3 \\
\hline Fig. S2 & $\mathrm{N}_{2}$ sorption isotherms of MSP1, MSP2, MSP4 & 4 \\
\hline Table S1 & BET surface areas and average pore size values of pristine MSPs. & 4 \\
\hline Fig. S3 & $\begin{array}{l}\text { SEM images of a) MSP1 b) MSP2 c) MSP4 d)Cht/MSP1:Ag } \\
\text { e) Cht/MSP2:Ag f) Cht/MSP4:Ag'. }\end{array}$ & 5 \\
\hline Fig. S4 & $\begin{array}{l}\text { TEM images of a) MSP1 b)MSP2 c)MSP4 d) MSP1:Ag } \\
\text { e) MSP2:Ag+, f) MSP4:Ag'. }\end{array}$ & 5 \\
\hline Fig. S5 & $\begin{array}{l}\text { Thermogravimetric analysis results of } \mathrm{MSP}(1 / 2 / 4): \mathrm{Ag}^{+} \text {and of } \\
\mathrm{Cht} / \mathrm{MSP}(1 / 2 / 4): \mathrm{Ag}^{+}\end{array}$ & 6 \\
\hline Fig. S6 & $\begin{array}{l}\text { Time dependent microcalorimetric investigation of chitosan } \\
\text { release from } \mathrm{Cht} / \mathrm{MSP}(1 / 2 / 4): \mathrm{Ag}^{+} \text {samples in HEPES }(\mathrm{pH} 7.2,25 \\
\mathrm{mM} \text { at } 36.5^{\circ} \mathrm{C} \text { ) buffer solution }\end{array}$ & 6 \\
\hline Fig. S7 & Reduction in bacterial colony number on MSP treatment & 7 \\
\hline Table S2. & $\begin{array}{l}\text { Change in E.coli and V.Cholerae cell length on Cht/MSP4:Ag } \\
\text { treatment based on SEM measurement. }\end{array}$ & 7 \\
\hline
\end{tabular}




\section{Nomenclature of prepared materials}

MSP1: Mesoporous silica nanoparticles with aspect ratio value 1

MSP2: Mesoporous silica nanoparticles with aspect ratio value 2

MSP4: Mesoporous silica nanoparticles with aspect ratio value 4

MSP1:Ag': Silver ion doped-mesoporous silica nanoparticles with aspect ratio value 1

MSP2:Ag': Silver ion doped-mesoporous silica nanoparticles with aspect ratio value 2

MSP4:Ag': Silver ion doped-mesoporous silica nanoparticles with aspect ratio value 4

Cht/ MSP1:Ag': Chitosan-coated and silver ion doped-mesoporous silica nanoparticles with aspect ratio value 1

Cht / MSP2:Ag+: Chitosan-coated and silver ion doped-mesoporous silica nanoparticles with aspect ratio value 2

Cht / MSP4:Ag: Chitosan-coated and silver ion doped-mesoporous silica nanoparticles with aspect ratio value 4

Cht / MSPs (1/2/4):Ag': Set of samples, Chitosan-coated and silver ion doped-mesoporous silica nanoparticles with all the aspect ratio values $(1,2,4)$ 
Fig. S1: TEM images of MSP1, MSP2, and MSP4

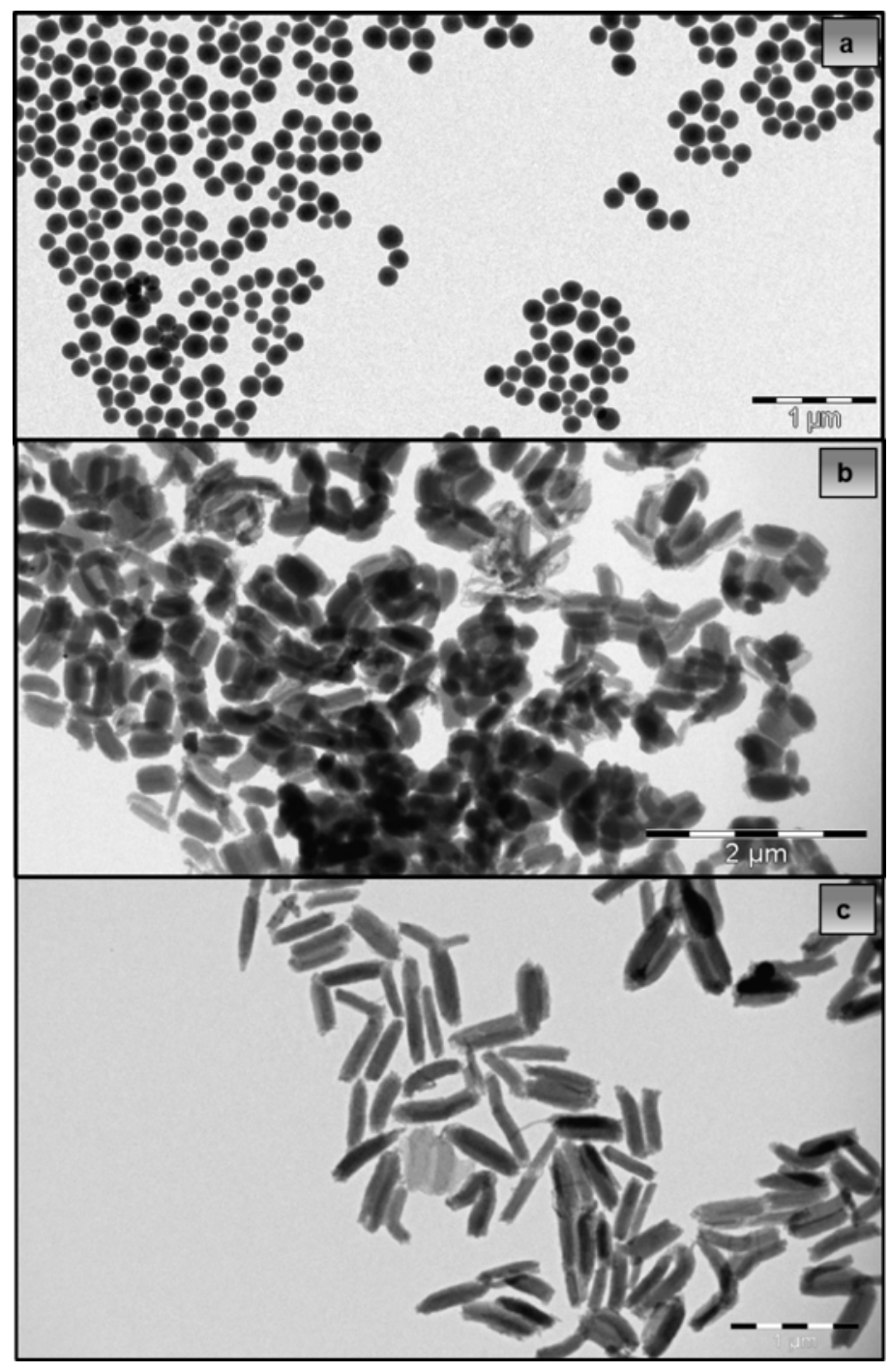


Fig. S2: N2 sorption isotherms of MSP1, MSP2, MSP4

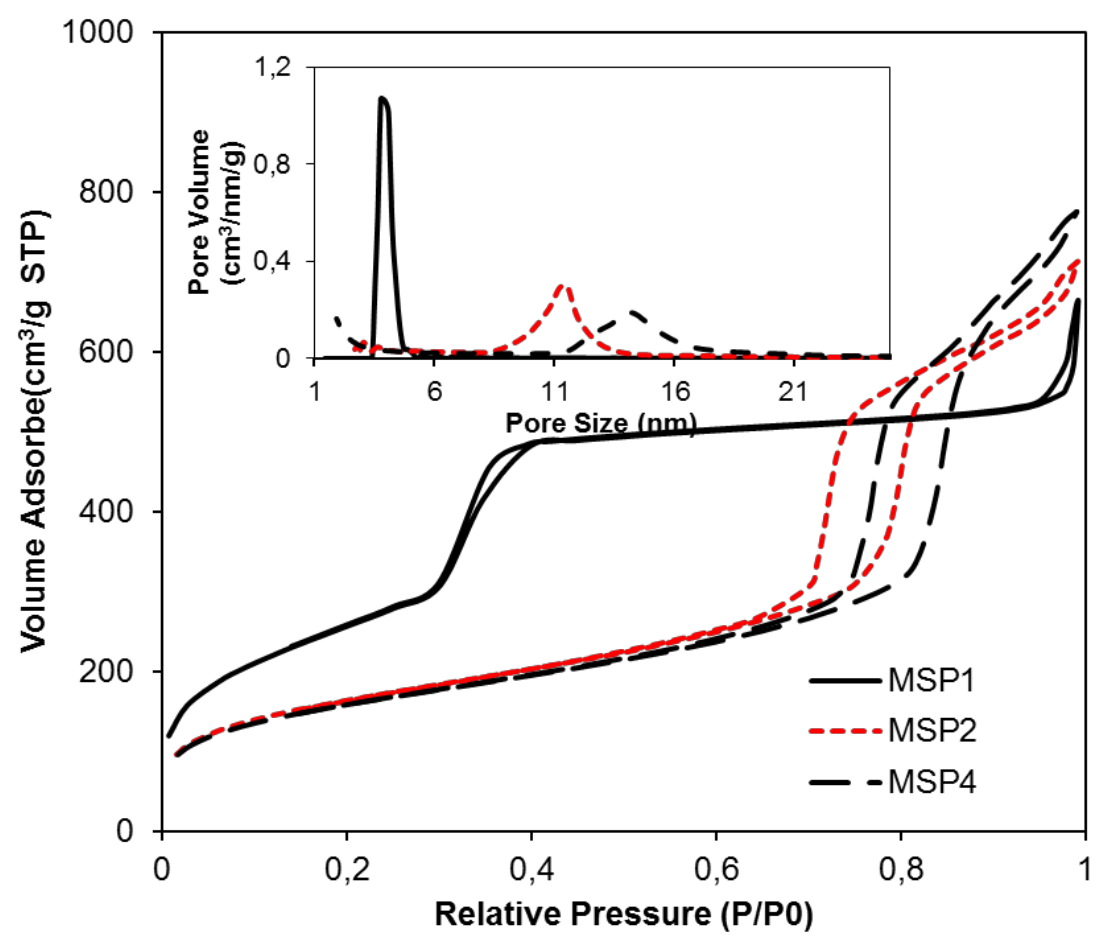

Table.S1: BET surface areas and average pore size values of pristine MSPs.

\begin{tabular}{ccc}
\hline SAMPLE & Surface Area $\left(\mathbf{m}^{2} / \mathbf{g}\right)$ & Pore size $(\mathbf{n m})$ \\
\hline \hline MSP1 & 915 & 3.8 \\
MSP2 & 583 & 11.4 \\
MSP4 & 575 & 14.2 \\
\hline
\end{tabular}


Fig S3. SEM images of a) MSP1 b) MSP2 c) MSP4 d) Cht/MSP1:Ag e) Cht/MSP2:Ag ${ }^{+}$ f) Cht/MSP4: $\mathrm{Ag}^{+}$.

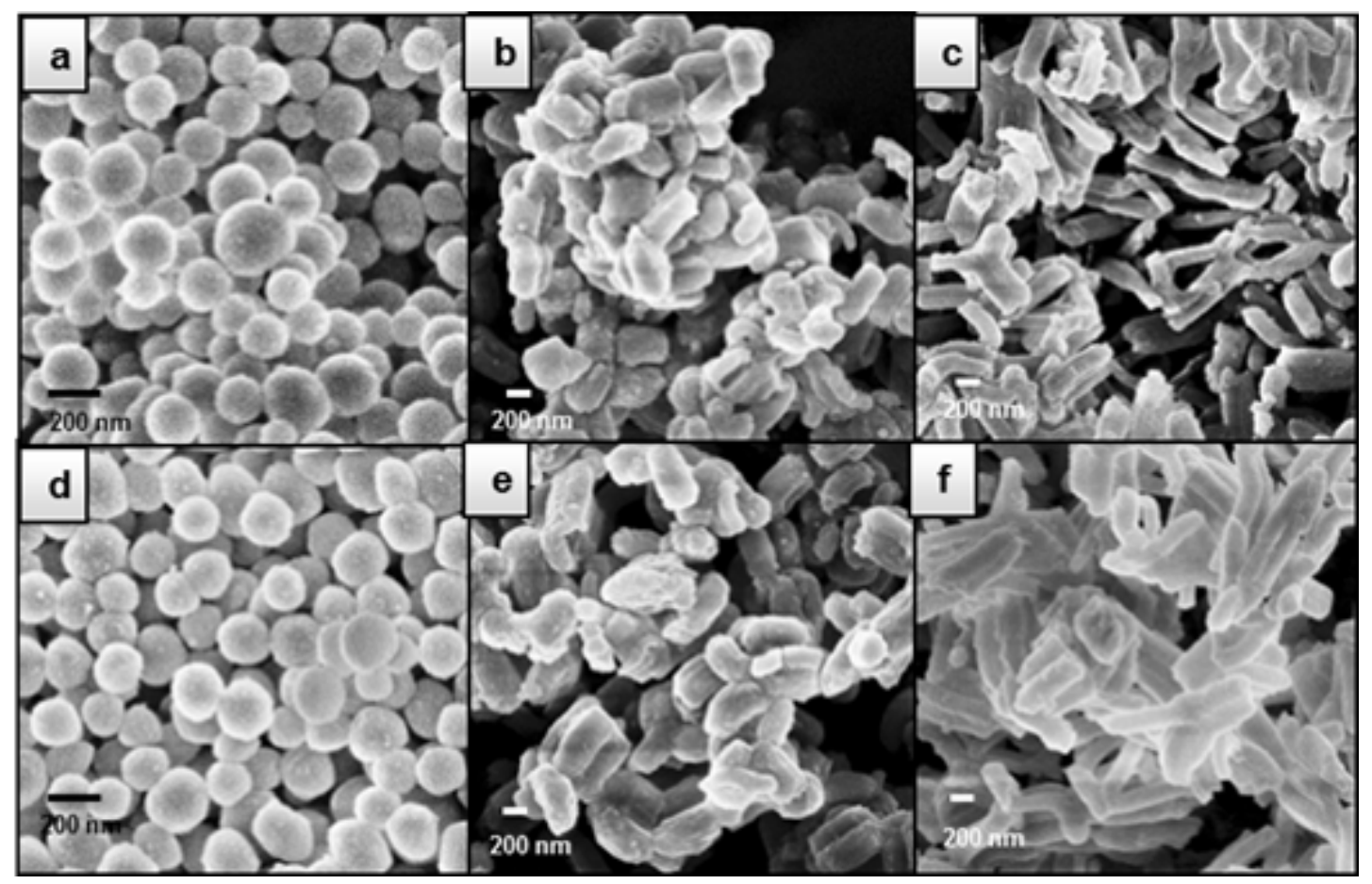

Fig S4. TEM images of a) MSP1 b)MSP2 c)MSP4 d)MSP1:Ag e)MSP2:Ag f)MSP4:Ag .

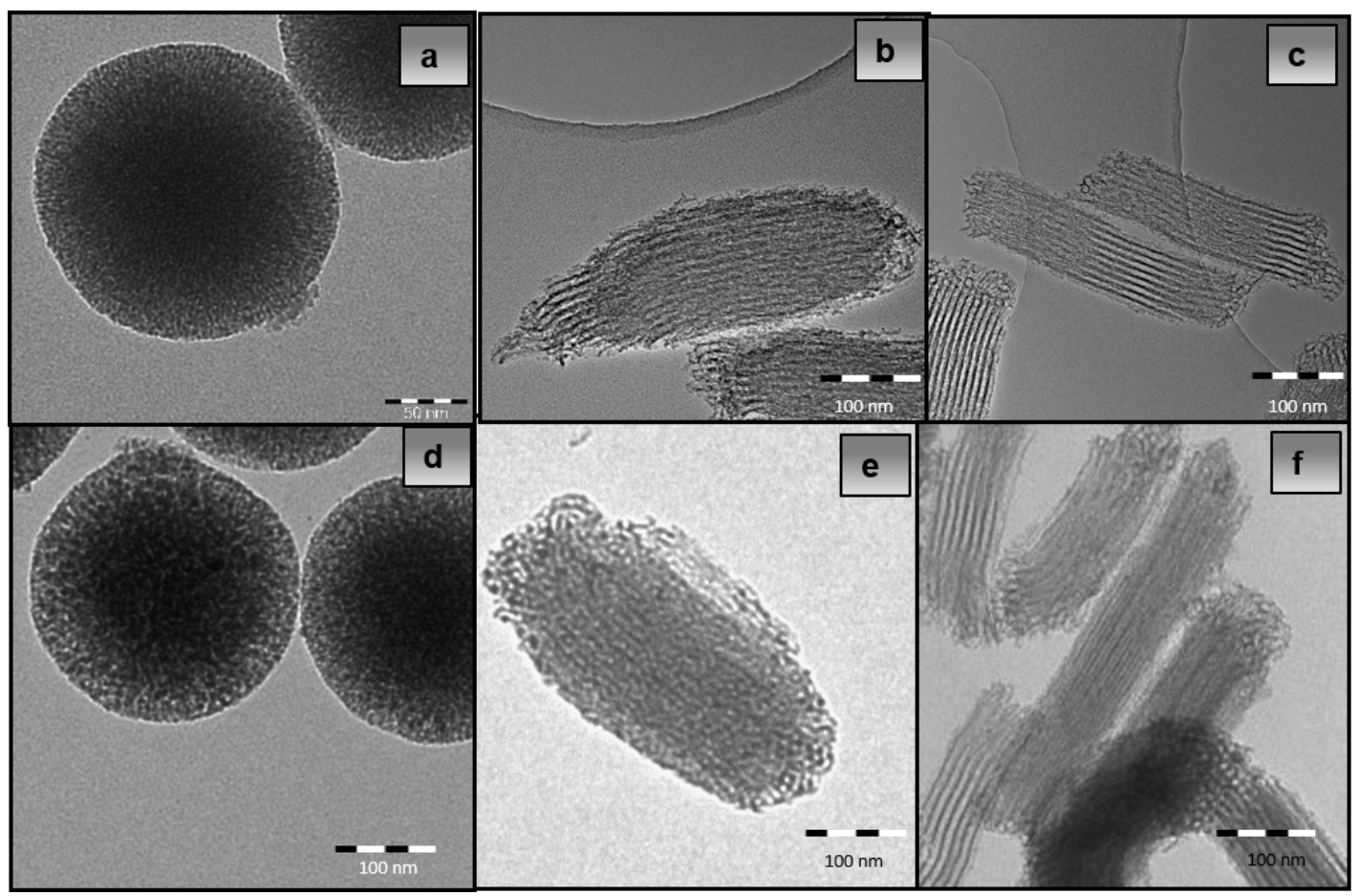


Fig. S5. Thermogravimetric analysis of $\mathrm{MSP}(1 / 2 / 4): \mathrm{Ag}^{+}$and $\mathrm{Cht} / \mathrm{MSP}(1 / 2 / 4): \mathrm{Ag}^{+}$

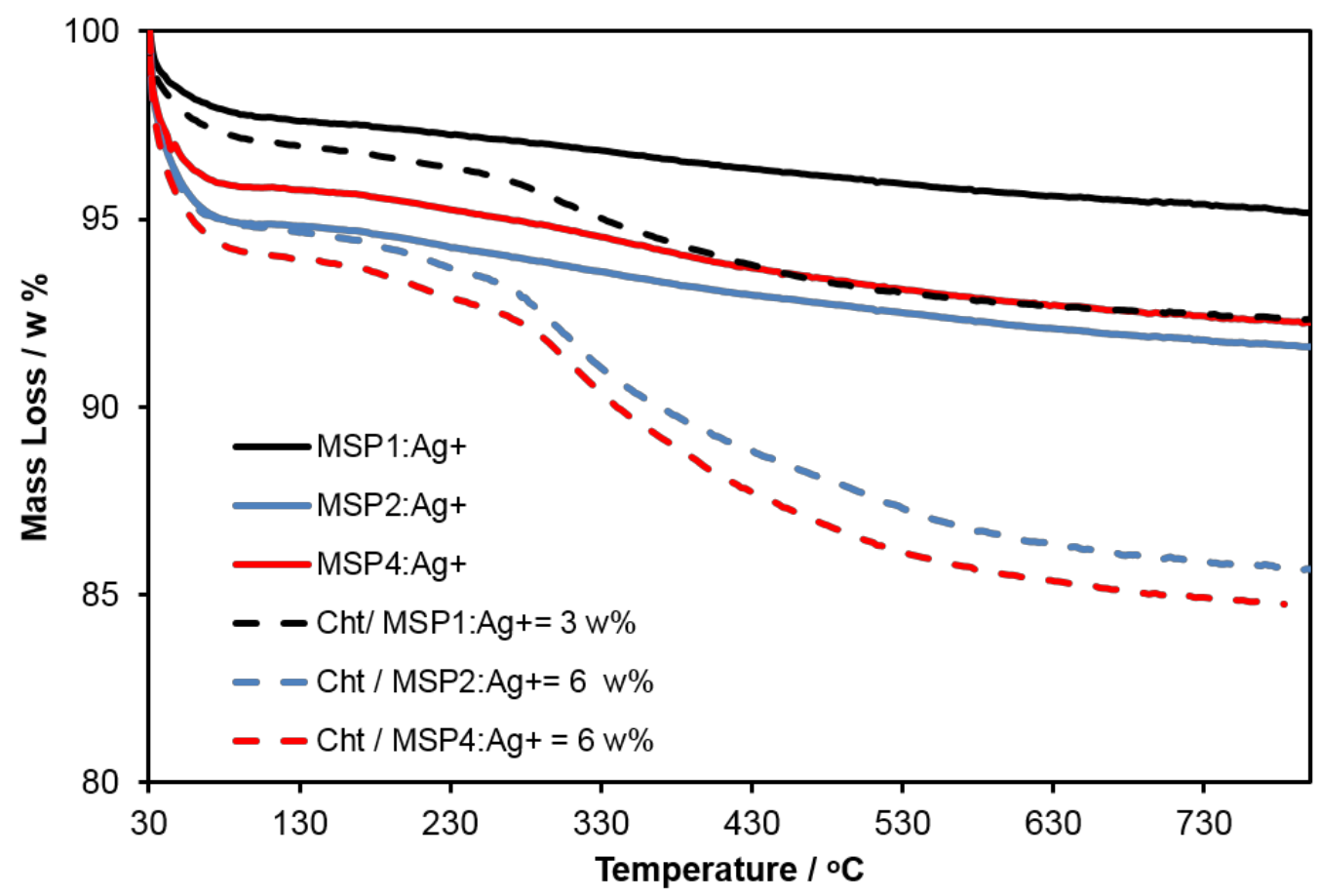

Fig. S6. Time dependent microcalorimetric measurement of chitosan release from Cht/MSP (1/2/4): $\mathrm{Ag}^{+}$samples in HEPES $\left(\mathrm{pH} 7.2,25 \mathrm{mM}\right.$ at $\left.36.5^{\circ} \mathrm{C}\right)$ buffer.

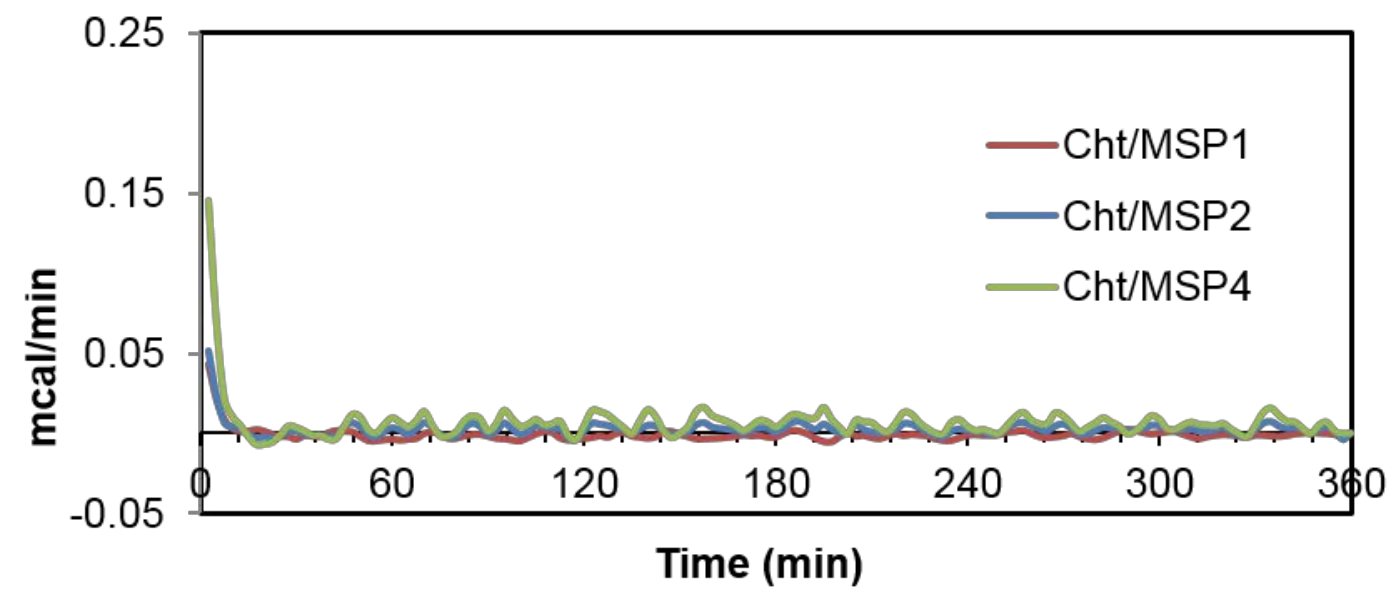


Fig. S7. LB plates showing reduction in number of colonies on MSP treatment.

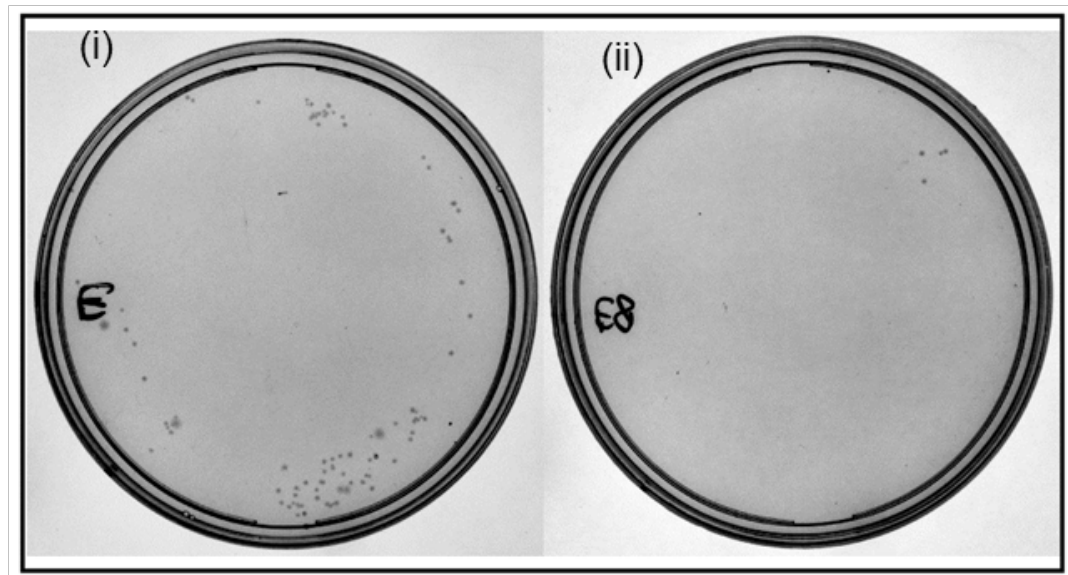

(i) E. coli

(ii) E. coli + Cht/MSP4: $\mathrm{Ag}^{+}$

Table S2: Change in E.coli and V.cholerae cell length on Cht/MSP4:Ag ${ }^{+}$treatment based on SEM measurement.

\begin{tabular}{|c|c|c|c|c|}
\hline \multirow{2}{*}{ Strain Name } & \multirow{2}{*}{$\begin{array}{l}\text { Total number } \\
\text { cell screened }\end{array}$} & \multicolumn{3}{|c|}{ Cell Length in $\mu \mathrm{M}$} \\
\hline & & $\begin{array}{l}\text { Normal } \\
(2.5 \mu \mathrm{m})\end{array}$ & $\begin{array}{c}\text { Elongated } \\
(2.5-10 \mu \mathrm{m})\end{array}$ & $\begin{array}{c}\text { Super-elongated } \\
\quad(>10 \mu \mathrm{m})\end{array}$ \\
\hline E.coli & 100 & 95 & 5 & ----------- \\
\hline E.coli+Chitosan/MSP4: $\mathrm{Ag}^{+}$ & 100 & 8 & 22 & 70 \\
\hline V.cholerae & 100 & 96 & 4 & ------------ \\
\hline V.Cholerae+Chitosan/MSP4: $\mathrm{Ag}^{+}$ & 100 & 40 & 52 & 8 \\
\hline
\end{tabular}

